\title{
Projected climate change impacts on climatic suitability and geographical distribution of banana and coffee plantations in Nepal
}

Dr Sailesh Ranjitkar, Nani Maiya Sujakhu, Kala Budhamagar, Saraswati Rimal Dr Jianchu Xu, Dr Juerg Merz, and Dr Robert J Zomer 


\section{Projected climate change impacts on climatic suitability and geographical distribution of banana and coffee plantations in Nepal}

Dr Sailesh Ranjitkar, Nani Maiya Sujakhu, Kala Budhamagar, Saraswati Rimal Dr Jianchu Xu, Dr Juerg Merz, and Dr Robert J Zomer

Working Paper 204 


\section{$80 \%$ \\ World \\ Agroforestry \\ Centre}

Correct citation: Ranjitkar, S.; Sujakhu, N.M.; Budhamagar, K.; Rimal, S.; Xu, J.; Merz, J.; Zomer, R.J. 2015. Projected climate change impacts on climatic suitability and geographical distribution of banana and coffee plantations in Nepal. ICRAF Working Paper 204. World Agroforestry Centre East and Central Asia, Kunming, China, 2015. 32 pp.

DOI: http://dx.doi.org/10.5716/WP15294.PDF

Titles in the Working Paper Series aim to disseminate interim results on agroforestry research and practices and stimulate feedback from the scientific community. Other publication series from the World Agroforestry Centre include: Agroforestry Perspectives, Technical Manuals and Occasional Papers.

Published by the World Agroforestry Centre

East and Central Asia Regional Programme

\% Kunming Institute of Botany, Chinese Academy of Science

3/F North Research Building

Heilongtan, 650201 Kunming

Yunnan Province, P.R. China

Tel.: +86-871-6522-3014 - Fax: +86-871-6522-3377

Email: icraf-eca@,cgiar.org

Webpage: www.worldagroforestry.org/eca

(C) World Agroforestry Centre 2015

Working Paper No. 204

Photo: Dr Juerg Merz

Disclaimer and copyright: The views expressed in this publication are those of the author(s) and not necessarily those of the World Agroforestry Centre. Articles appearing in this publication may be quoted or reproduced without charge, provided the source is acknowledged. All images remain the sole property of their source and may not be used for any purpose without written permission of the source. 


\section{About the authors}

Dr Sailesh Ranjitkar is an ecologist leading the tree diversity and domestication programme at the World Agroforestry Centre's East and Central Asia regional programme. He holds a PhD in Plant Science from the Chinese Academy of Sciences, and an MSc in Botany from Tribhuvan University, Nepal. A native of Nepal, Dr Ranjitkar worked on biodiversity (medicinal plants) conservation, high-altitude ecosystem and climate change, in conjunction with different organizations. His current research includes phenology, agroforestry, species distribution modelling, and crop vulnerability.

Nani Maiya Sujakhu is a PhD candidate at Kunming Institute of Botany, Chinese Academy of Sciences. Ms Sujakhu holds a master degree in Mountain Environment Science from Khwopa College, Tribhuvan University, Nepal. Her PhD research focuses on community livelihood vulnerability and strategies for adaptation to climate change in the Asian highlands.

Kala Budhamagar is a Crop Development Officer at Department of Agriculture, Ministry of Agriculture Development, Nepal. She holds a bachelor degree in agricultural science from the Institute of Agriculture and Animal Science, Tribhuvan University, Rampur Nepal. She is currently working on her master thesis focuses on soil science and banana plantation.

Saraswati Rimal is a Master student of Soil Science at the Agriculture and Forestry University, Rampur, Chitwan, Nepal. She holds a bachelor degree in agriculture from the Institute of Agriculture and Animal Science, Tribhuvan University, Nepal. Her master dissertation focuses on the soil fertility at coffee plantation sites in two districts of Nepal.

Dr Jianchu Xu is an internationally respected leading ethno-ecologist who works in coupled humanenvironmental systems. His current research includes investigation of early warning signals of global change, trans-boundary water governance, landscape restoration, ecosystem services and their resilience, agriculture, and integrative conservation. Dr Xu leads the World Agroforestry Centre's East and Central Asia regional programme.

Dr Juerg Merz is an International Advisor at HELVETAS Swiss Intercooperation Nepal. Dr Merz coordinates the project design and supports the project management team. He has worked on different watershed management projects in India, Pakistan, Nepal, Bhutan, Tajikistan, China, and New Zealand as a hydrologist, erosion specialist, information and communication specialist, advisor, and team leader. During his time with the International Centre for Integrated Mountain Development (ICIMOD), he conducted his PhD research on hydrology, water management and erosion.

Dr Robert J. Zomer is coordinating climatic and hydrological modelling activities throughout the central Asian region. He is a landscape ecologist with a broad background in plant community, forest and agricultural ecology, and advanced skills in statistical analysis, geographic information systems (GIS), remote sensing, environmental modelling, and landscape-level spatial analysis. He is currently a visiting Professor at Kunming Institute of Botany and a Senior Landscape Ecologist at the World Agroforestry Centre's East and Central Asia regional programme.

\section{Acknowledgment}

The project was supported by ICIMOD SERVIR-Himalaya (joint initiative of NASA and USAID), a programme that promotes innovative application of earth observation resources and geospatial technology for climate change related decision making and to translate science into sustainable policy and practices that addresses the development challenges posed by climate stresses. Research was part of IDRC (Canada)-supported project on Building Effective Water Governance in the Asian Highlands. Additional support was also provided from the CGIAR Research Program on Forests, Trees and Agroforestry (CRP6) and Climate Change, Agriculture, and Food Security (CRP7). Thanks to Santosh Rana, Raju Jati (LiBird Nepal), and the Elam and the CoPP team (HELVETAS Nepal) for their help in field data collection, and Dr Robert Hijmans of the University of California-Davis for providing down-scaled CIMP5-ESMs. We acknowledge Sander Van de Moortel for editing this document. 


\begin{abstract}
Global circulation models all forecast that climate change will increase mean temperatures and change precipitation regimes. Change in bioclimatic conditions will impact the productivity of high-value agricultural crops. As a result of this change, traditional cash crop-growing regions may disappear and new regions may become available. This is a slow process but impact will be severe. With proper site-specific crop management, agricultural production may even benefit in the future. One form of site-specific crop management is to grow crops in the best suitable locations established through cost-effective, quick and scientific methods. Such methods are suitable for developing countries like Nepal where climate change is projected to have major impacts on the farming system. In order to make sources of cash crops sustainable, farmers, farming communities, and cooperatives in the supply chain of these crops in Nepal need to know where these cash crops will grow in the future and how the suitability of current growing areas will change over time. Farmers and their associated supply chains need to develop appropriate site-specific mitigation and adaptation strategies for both the short and the long term to guarantee a continuation of these various cash crops and to provide support to maintain the improved livelihoods of farmers who already invested in these commodities.
\end{abstract}

This study developed a production suitability map for two major cash crops in Nepal, banana and coffee, using advanced spatial modelling combined with with extensive fieldwork and ground truthing. A spatial model of the agro-ecological suitability of banana and coffee production zones in Nepal was developed using ground data on crop plantations and farmer surveys conducted in two districts for each crop. The future changes in distribution of the climatically suitable zones for these cash crops were projected using an ensemble of climate projections derived from the results of 19 Earth System Models provided by the Coupled Model Inter-comparison Project-Phase 5 (CMIP5). In addition to spatial modelling, conditions of crop plantations at two districts were closely observed for each crop, including through farmer surveys and soil analysis. Soil fertility problems and nutrient deficiency in plants were identified as important components of suitability for plantations and for identifying site-specific management approaches. Two master students conducted the research on soil at plantation sites for each of the two crops representing climatically high and low suitability zones.

The spatial analysis data is available online from the Asian Highlands Knowledge Platform (http:// landscapeportal.org/layers/ and http://asianhighlands.org/) to provide online access and interactive mapping of the suitable production zones and to support policy dialogue and sub-sector planning. Detailed suitable production zones for banana and coffee plantations, the impact of climate change as identified by changes in climatically suitable zone, and suitable locations for mixed cropping or intercropping of two crops are identified. It is our hope that this will help both land use planners and managers of commercial plantations to better meet the challenges of climate change in Nepal and the Asian Highlands.

\title{
Keywords
}

Chitwan, Kavrepalanchok, Lamjung, Nepal, farming systems, farmers, banana, coffee, soil, climate change. 


\section{Contents}

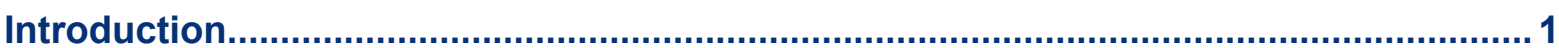

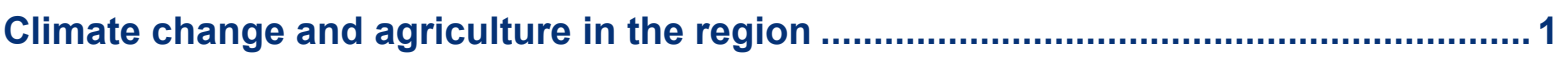

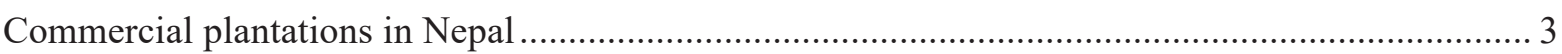

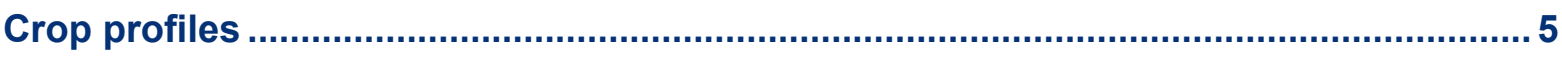

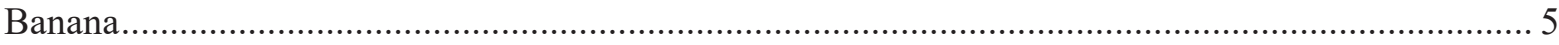

Coffee

Two crops, agro-ecological zone and bioclimate ...................................................

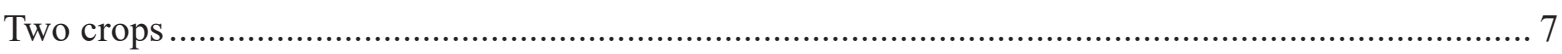

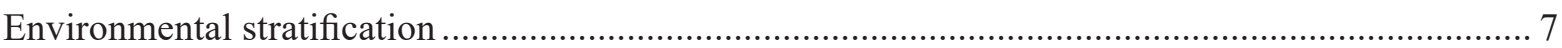

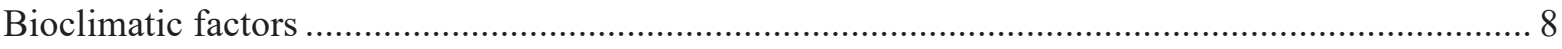

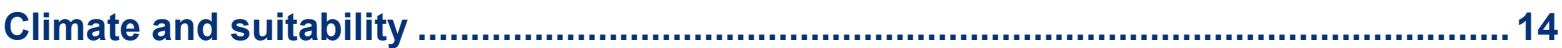

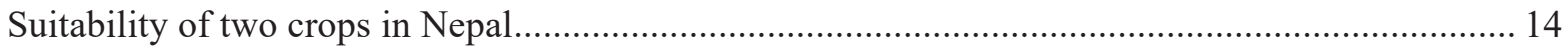

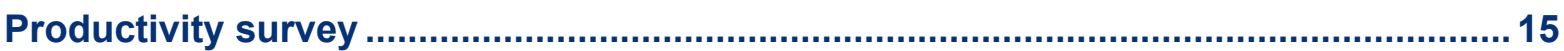

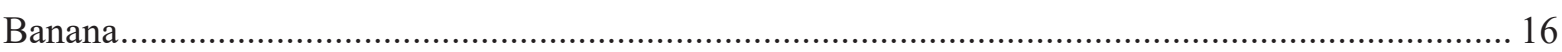

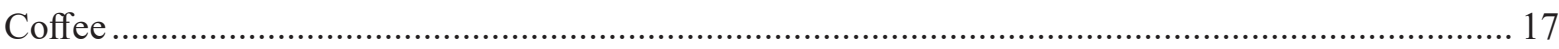

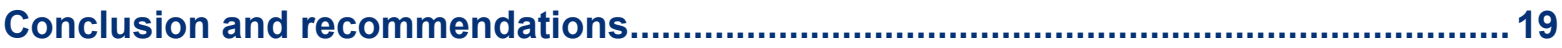

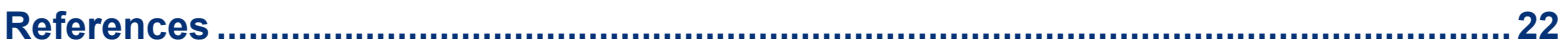




\section{Introduction}

The results of this study to model the distribution and climate change impacts on coffee and banana plantations in Nepal were produced under the Spatial Modelling of Climate Change Impacts on Two Major Cash Crops in Nepal project. This project supplemented the Building Effective Water Governance in the Asian Highlands project that prepared an environmental stratification and ensemble bioclimatic analysis of the Asian Highlands region. Implementing similar methods to develop the ensemble bioclimatic layers and to describe environmental stratification for Nepal, the current project models crop suitability and provides for a knowledge platform for the dissemination of these results. This work demonstrates one step in an approach to creating a crop suitability model and geospatial database for important crops in Nepal. Using this approach, a model that projects the impacts of bioclimatic conditions onto the suitable production zone of high-value agricultural crops was developed. In addition, a farmers' survey was conducted in the high and low production zones for each crop, which provided the basic information for the delineating sustainable cultivation practices of these two crops and actual soil condition. For each crop, a profile that includes a brief overview, and a description of its geographic distribution and economic importance are provided, followed by a presentation of the crop's life cycle, and graphics that illustrate bioclimatic parameters that significantly determine the production suitability for the crops. The presentation continues with case studies from two districts for each crop that provide further details on growth thresholds related to soil conditions, water availability, and temperature. Selected bioclimatic variables are provided, as well as physical factors, land cover layers, global environmental stratification strata, and suitability models for each crop.

This Working Paper report is intended to provide information useful to understand potential climaterelated threats to these two major cash crops in Nepal. An environmental stratification, equivalent to agro-ecological zonation, has been applied specifically for the relevant regions in Nepal and used to model the distribution and climatic crop suitability for these two crops. This spatial analysis provides a useful reference tool to evaluate climate-based threats to these crops across Nepal. As such, it can provide decision support to land use planner and commercial plantation managers to plant "the right crop in the right place" and to take into account both current and future environmental factors. The study seeks to contribute to a more comprehensive understanding of the possible impacts of climate change on the future distribution of important cash crops in Nepal, and to provide decision makers with an evidence-based approach to defining strategies for agricultural adaptation that can be supported or extended by the government, nongovernmental organizations (NGOs), and other implementing partners.

\section{Climate change and agriculture in the region}

The results from the Building Effective Water Governance in the Asian Highlands project (http:// www.asianhighlands.org) show that the average annual temperature in the highlands will increase by $1.7^{\circ} \mathrm{C}$ to $2.6^{\circ} \mathrm{C}$ by the year 2050 . Likewise, it is estimated that the annual precipitation in this area will increase by $4 \%$ to $8 \%$ (up to $120 \mathrm{~mm}$ more per year). These results are based on state-of-theart analysis using a multi-model downscaled (near $1 \mathrm{~km}$ resolution) ensemble $(\mathrm{n}=63)$ of the latest projections made available through the Coupled Intercomparison Model Project — Phase 5 (CIMP5) applied across four representative concentration pathways (RCPs), or future climate scenarios. These data sets now allow us to model suitability and more specific issues related to the impact of projected climate change on specific crops. 
Agriculture is highly dependent upon stable climatic conditions. Therefore, it is one of the sectors where climate change impacts are expected to hit hardest (Hertel et al 2010). The predicted changes in future climates have the potential to expose agricultural systems to conditions not experienced before. The agricultural sector will suffer in multiple ways and there will be a drastic shift in current land use and crop suitability. In addition, there could be an increased variability of production, farm incomes and food availability including changes in the geography of production (Battisti and Naylor 2009; Lobell and Burke 2010; Roudier et al 2011). Declining harvests are exacerbated by an increase in disease and pest infestation, as well as by a decline in biodiversity (Waldmüller 2012). Increasingly pressurized to grow more food to sustain a growing population, sustainable food security is at risk. The Himalayan region, even more so than most mountainous regions, is highly vulnerable to climate change. Its effects are increasingly evident within agricultural systems, and both farmers and policy makers throughout the region recognize its effects. Climate change is projected to have significant and substantial impacts on bioclimatic and agro-ecological zones, hydrology, ecosystems, and farming systems throughout the region. These impacts may pose a major risk for various commercial plantations in the foreseeable future. Knowing the implications of projected climate change for specific crops is essential, particularly for tree crops which have a prolonged immature stage before production and are expected to produce for many years. It is paramount to understand where these can be planted, both in the present and in the near to midfuture.

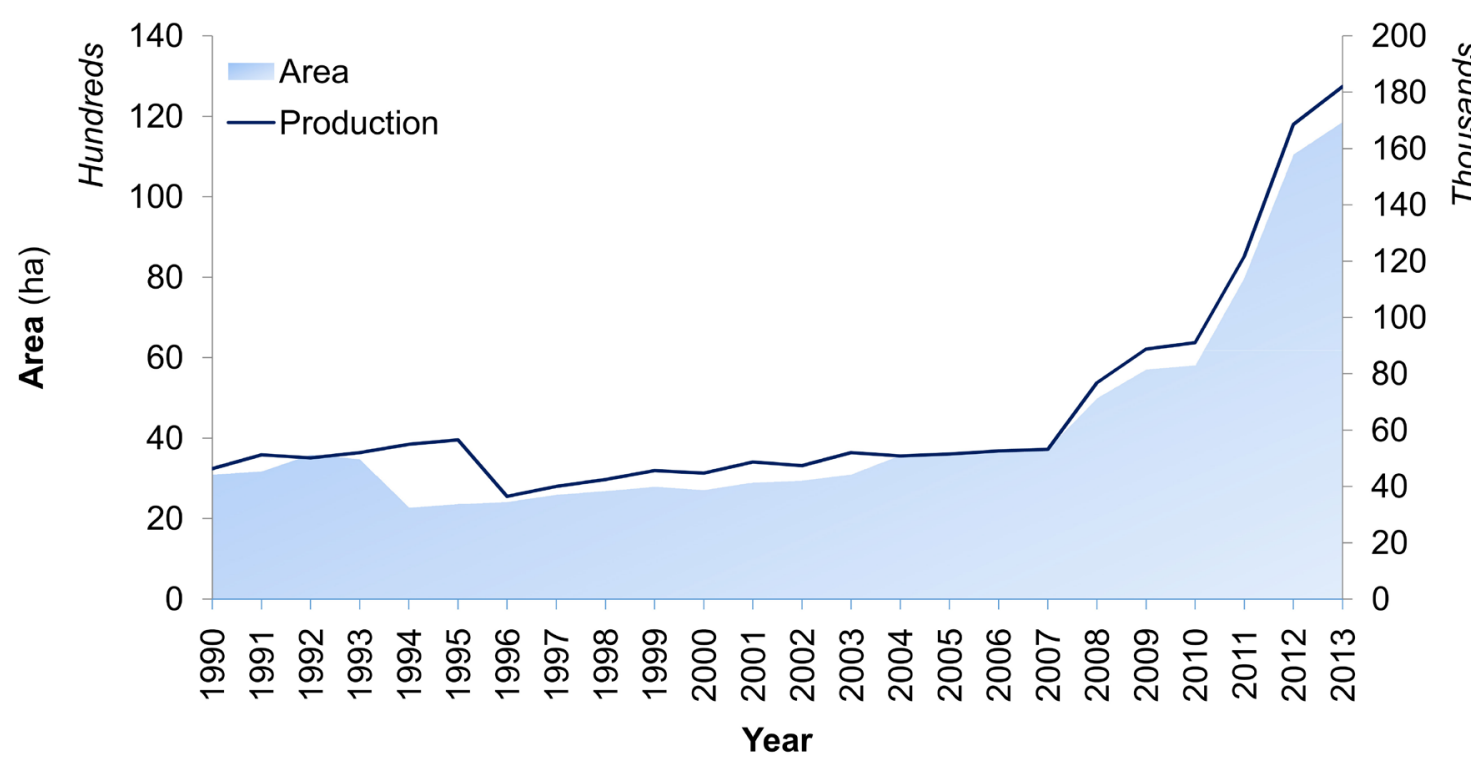

Figure 1: Banana production and plantation areas from 1990 to 2013 (MoAD 2013; MoAD 2014; FAOSTAT 2015)

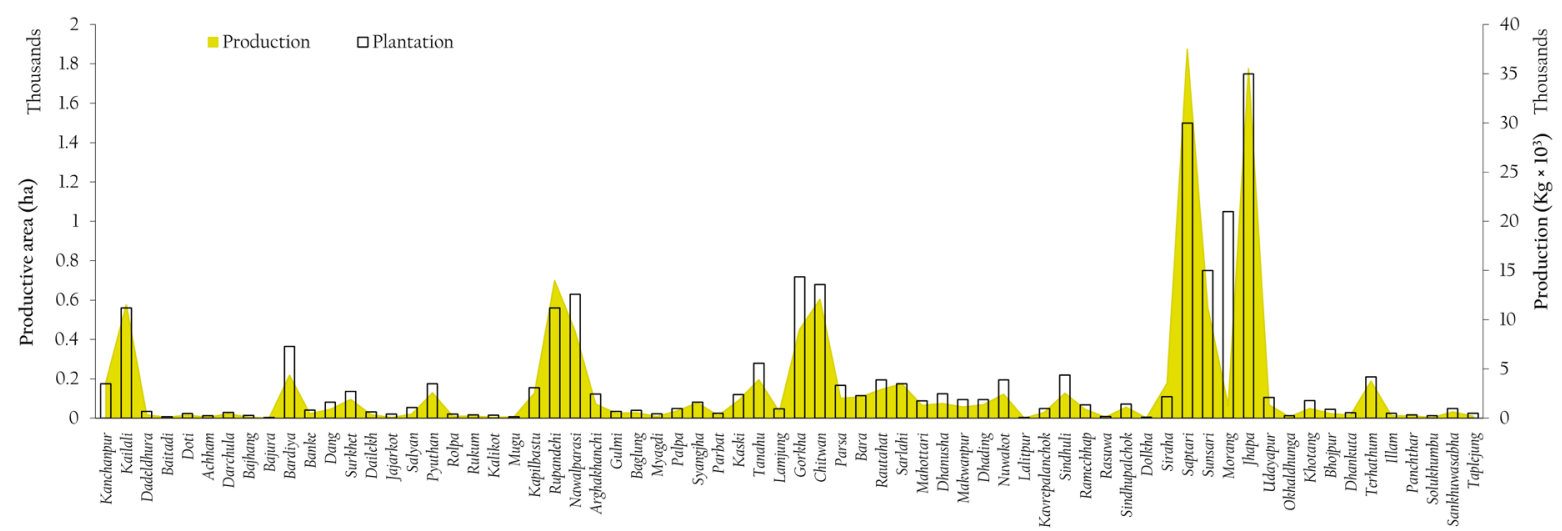

Figure 2: Banana production and plantation areas in different districts of Nepal 


\section{Commercial plantations in Nepal}

In Nepal, and throughout the Himalayan mountain region, much effort, resources and investment are being focused on the promotion of various cash crops with the intention of improving the livelihood status of small farmers through diversification and cash crop cultivation. Recently, the Ministry of Agriculture and Development of Nepal endorsed the Agricultural Development Strategy 2013 which promotes several cash crops. Likewise, the Nepal Trade Integration Strategy focuses on different agricultural cash crops.

Since 2007, Nepal witnessed a tremendous growth in banana and coffee plantations (Fig. 1). Banana is presently known to be grown in 67 districts in Nepal. The banana output accounts for 0.4 percent of the Agriculture Gross Domestic Product. In 2014, the total productive area of banana plantations expanded to 12861 ha and saw a total production increase to $208244.55 \mathrm{~kg} \times 10^{3}$ (MoAD 2014). Figure 2 presents banana plantations and production distribution in 2013-2014, according to the national crop production database from the Ministry of Agriculture Development (MoAD). Banana production is highest in Eastern Nepal, where plantation areas are also larger than in other parts of the country (MoAD 2014), whereas production is comparatively lower in many districts of Central and Western Nepal (Fig. 2). Market and social acceptance are major drivers for the increased demand for banana, the fruit being available in almost all seasons and gaining acceptance at the various festivals. If Nepal steps towards commercial banana farming, it has the potential to yield up to 20 $\mathrm{kg} \times 10^{3} \mathrm{ha}^{-1}$, while current data shows an average of $16.2 \mathrm{~kg} \times 10^{3} \mathrm{ha}^{-1}$ (MoAD 2014).

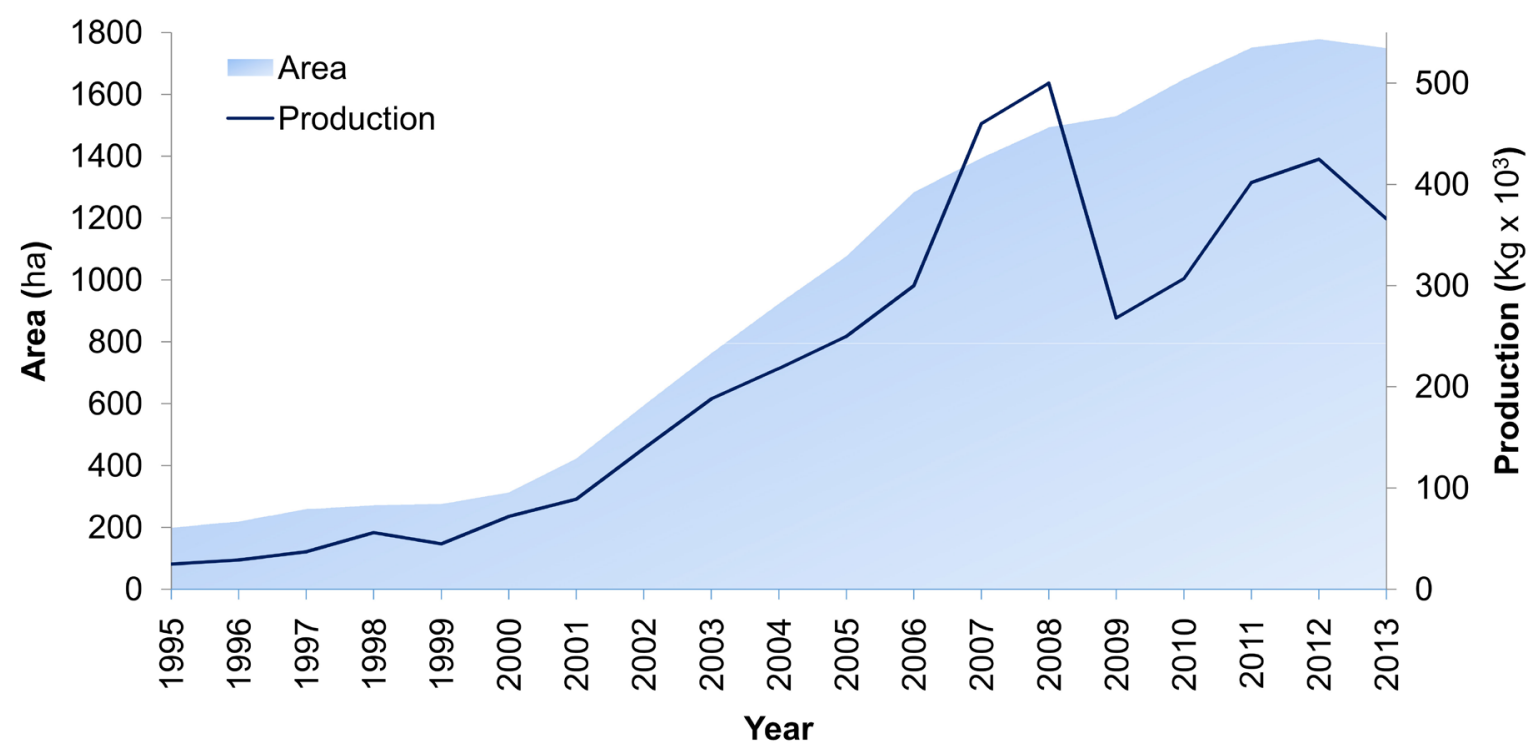

Figure 3: Coffee production and plantation area from 1995 to 2013 (MoAD 2013; MoAD 2014; FAOSTAT 2015)

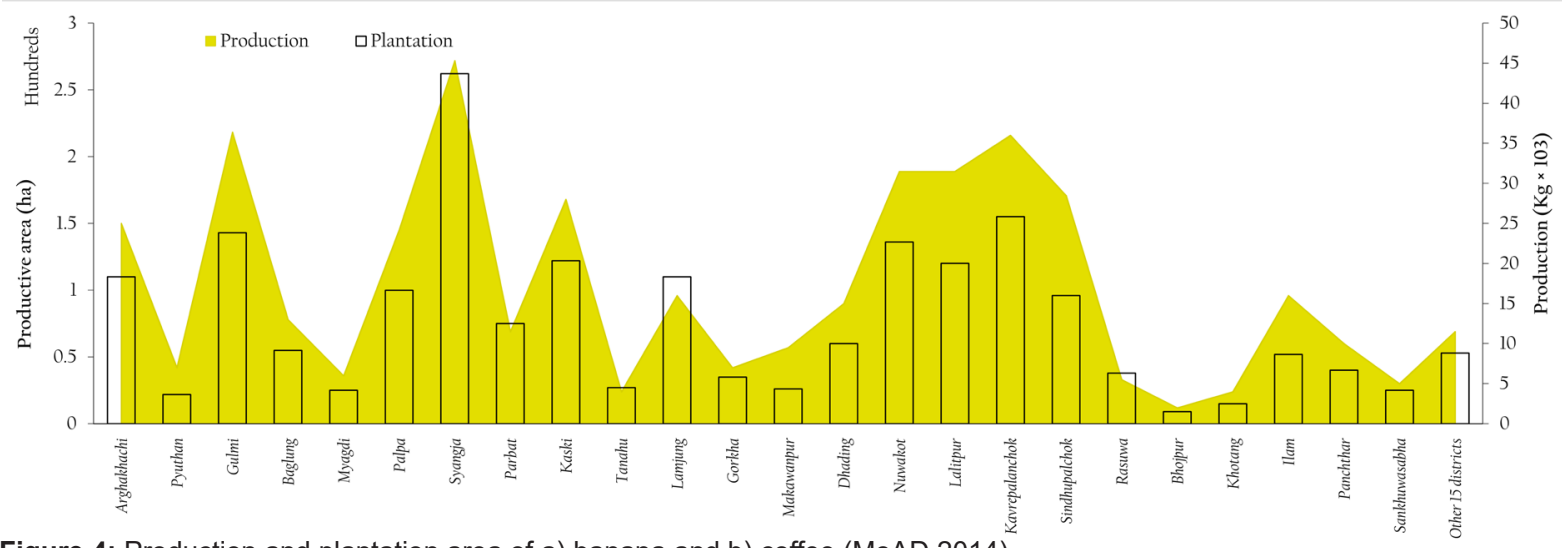

Figure 4: Production and plantation area of a) banana and b) coffee (MoAD 2014) 
After 2000, coffee plantations expanded steadily, while the production rather irregularly (Fig. 3). At present, coffee is known to be grown in 42 districts in Nepal. The total productive area of coffee plantations (Fig. 4) was 1911 ha in 2013-2014, and total production was around $429 \mathrm{~kg} \times 10^{3}$ (MoAD 2014). Current data shows the coffee bean production in Nepal at around 0.22 tonnes per hectare on average (MoAD 2014).

Tourism is one of Nepal's major sources of income and an important contributor to its economy. In Nepalese society, coffee is not the beverage of choice but the increasing number of tourists has raised the demand for coffee, as evidenced by a strong and significant positive linear relationship between the increasing number of tourists and higher coffee production (Fig. 5a). Another important driver is demand from international markets, as evidenced by a strong and significant positive linear relationship between increasing export and higher coffee production (Fig. 5a). Coffee became one of the most important agricultural product to be exported from the country, and this expanding market is the only driver of farmers' tendency to cultivate coffee. As a result, many organizations including the government are promoting commercial coffee plantations in the mid-hills of different parts of Nepal.

Commercial plantations of important cash crops such as banana and coffee play a vital role in the Nepalese economy. Banana and coffee are becoming very important sources of livelihoods for several thousands of smallholders and marginal farmers, and provide employment for millions of
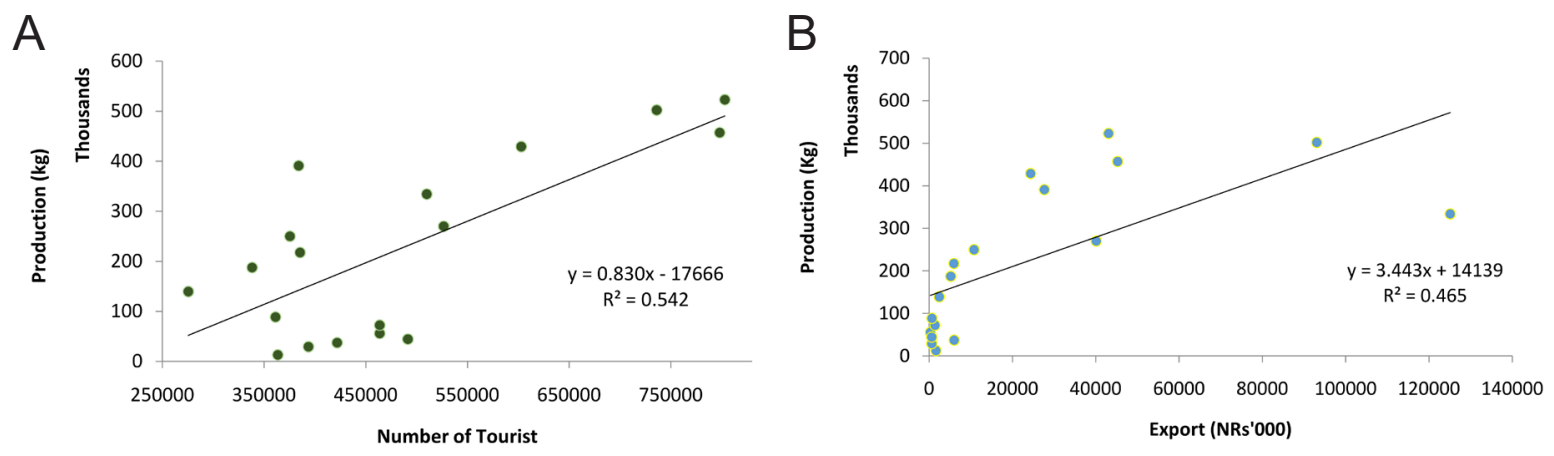

Figure 5: Linear regression for a) tourist number from 1995 to 2013; and b) export of coffee and coffee production from 1995 to 2013

plantation workers. Details of more than 30000 coffee farmers in 2014 are recorded in the national statistical database (MoAD 2014), while the recorded number of coffee farmers in 2013 was 27000 (MoAD 2013). This indicates the popularity of coffee plantations that lead to an increasing number of coffee farmers. During this study, we were unable to get an official record of banana farmers, but the number of banana farmers is much higher than of coffee farmers, and this number is increasing tremendously because of the growing market. While the export earnings from plantation crops like coffee played a significant role in the economic development of Nepal, the increased production of locally consumed crops like banana helps reduce the import of such crops. 


\section{Crop profiles}

\section{Banana}

Brief overview: Bananas are the fourth most valuable food crop in developing world, following rice, wheat, and maize (Frison et al 2004). Bananas are large, perennial herbs, and range from 2-9 $\mathrm{m}$ in height. They are native to southeast Asia and the Indian subcontinent, and are currently grown in more than 110 countries (Heslop-Harrison and Schwarzacher 2007; FAOSTAT 2015). They grow in a wide range of agro-ecological environments and have varied human uses, from the edible bananas of the tropics, to as ornamental plants and hedges, to fibre-yielding plants. Globally, over $100 \mathrm{~kg} \times 10^{3}$ of bananas are grown annually, Nepal ranks $47^{\text {th }}$ in banana production (FAOSTAT 2015). Banana is a pantropical crop, but production is currently concentrated in tropical to warm temperate regions in India, China, African countries, the Caribbean, and Latin America (Machovina and Feeley 2013). They may also be grown in temperate, relatively frost-free climates, but generally fail to fruit due to cool temperatures (Nelson et al 2006). In Nepal, banana is mostly grown in the Terai region below $300 \mathrm{~m}$ where most commercial plantations are located. Banana is also grown in agroforestry systems with other commodities in hilly regions up to $1800 \mathrm{~m}$ in different parts of Nepal. In Papua New Guinea, banana fruiting is reported at up to $2000 \mathrm{~m}$ (Nelson et al 2006).

Life cycle: Banana plants are known for their ability to regenerate rapidly from corms. They easily sprout from underground root stalks that grow horizontally from a mature banana tree. After 10 to 15 months, the tree sprouts and forms a stalk, then grows leaves. Banana sprouts female flowers, sterile flowers and finally male flowers. Fruits develop from the female flowers without pollination, but generally fail to fruit in cool temperatures (Nelson et al 2006). Temperature is very important in different phases of banana growth; about $27^{\circ} \mathrm{C}$ is optimal for growth and production (Fig. 6).

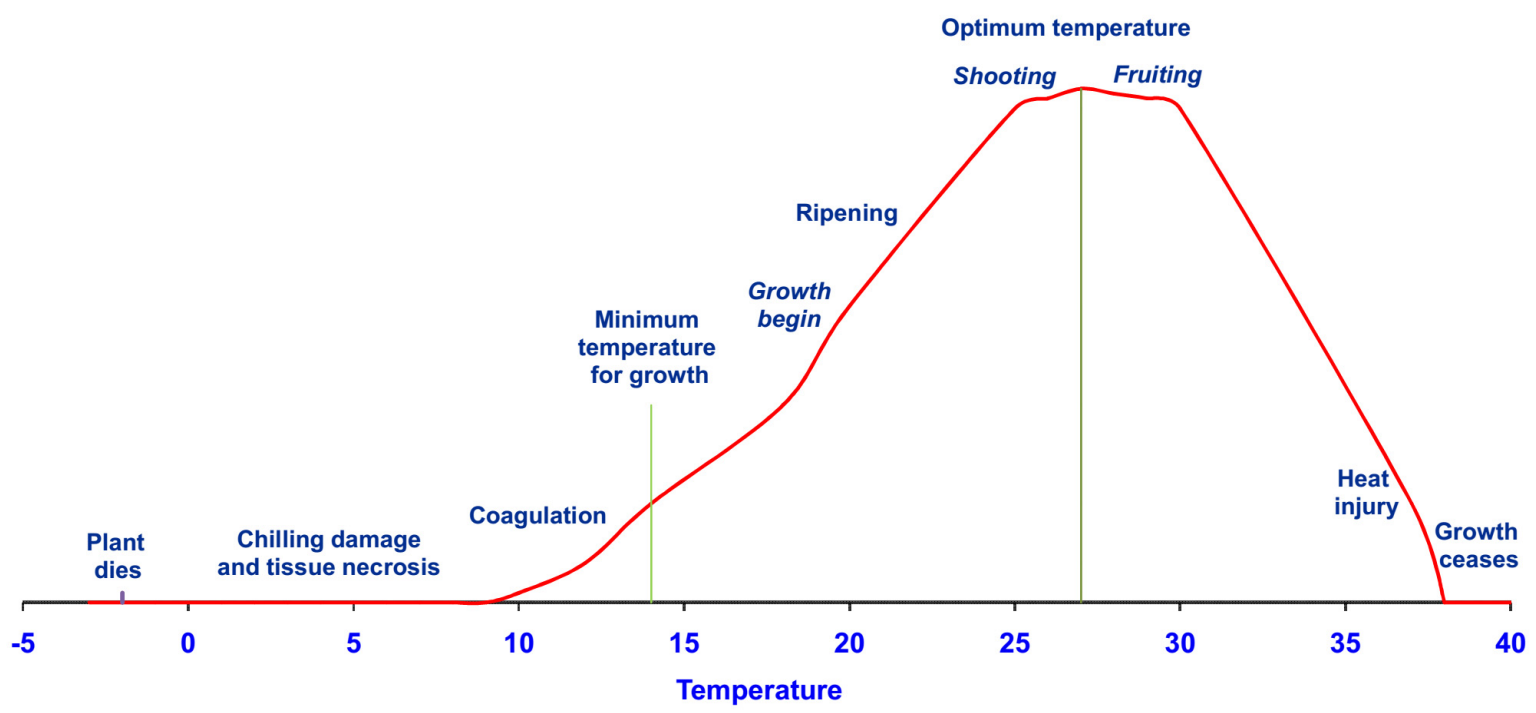

Figure 6: Growing phase of banana and role of temperature, redrawn based on available literature (e.g. Nelson et al. 2006; Deuter et al. 2012; Machovina and Feeley 2013) 


\section{Coffee}

Brief overview: Coffee is the main cash crop in many developing countries in the tropics. It is one of the most popular beverages and an important global commodity which provides the livelihoods of 100 million people (Davis et al 2012; Rodríguez et al 2013; Kutywayo et al 2013; Bunn et al 2014). The coffee trees cultivated worldwide belong to two species: Arabica coffee Coffea arabica and Robusta coffee C. canephora var. robusta (Wintgens 2004). Two-thirds of the global coffee market is represented by Arabica coffee (Nzeyimana et al 2014). Arabica coffee is a small tree attaining heights of about $4 \mathrm{~m}$ and that stands out from a deep root system penetrating the soil up to $1 \mathrm{~m}$ deep (Wintgens 2004). It is native of the mountains of Ethiopia, where it grows in the wild at altitudes of 1300 to $2000 \mathrm{~m}$ (Wintgens 2004). At present it is grown in more than 80 countries, primarily in the equatorial regions of the Americas, Southeast Asia, India and Africa (FAOSTAT 2015). Coffee is grown in tropical to warm temperate zones between latitudes $22^{\circ} \mathrm{N}$ and $26^{\circ} \mathrm{S}$ (Descroix and Snoeck 2004). Production of coffee is concentrated in Latin America, African countries, Indonesia, Vietnam and India. They may be grown in colder but frost-free regions. In Nepal, the crop is grown in the mid-hills at altitudes between 600 and $2000 \mathrm{~m}$ where most commercial plantations are located.

Life cycle: Six basic environmental factors should be considered for the cultivation of coffee (Descroix and Snoeck 2004). Temperature, water availability, sunshine intensity, wind, type of soil, and topography are very important for coffee plantations as these factors affect the phenology/ life cycle of the coffee plant. Arabica coffee needs about 1400 to $2000 \mathrm{~mm}$ annual rainfall. Direct sunlight is preferable to stimulate flowering, but good shade is necessary to attenuate the effect of extreme high and low temperatures (Descroix and Snoeck 2004). The low productivity zones for coffee are reported mainly at high altitudes with high rainfall and low temperatures (Nzeyimana et al 2014). The productivity of Arabica coffee is tightly linked to climatic variability. Temperature in particular is a very important driver in different phases of the life cycle (Davis et al 2012). Temperature variations play a critical role in coffee behaviour. Arabica coffee's maximum diurnal temperature tolerance is $19^{\circ} \mathrm{C}$ (Descroix and Snoeck 2004). The effects of temperature on coffee are presented in the figure 7.

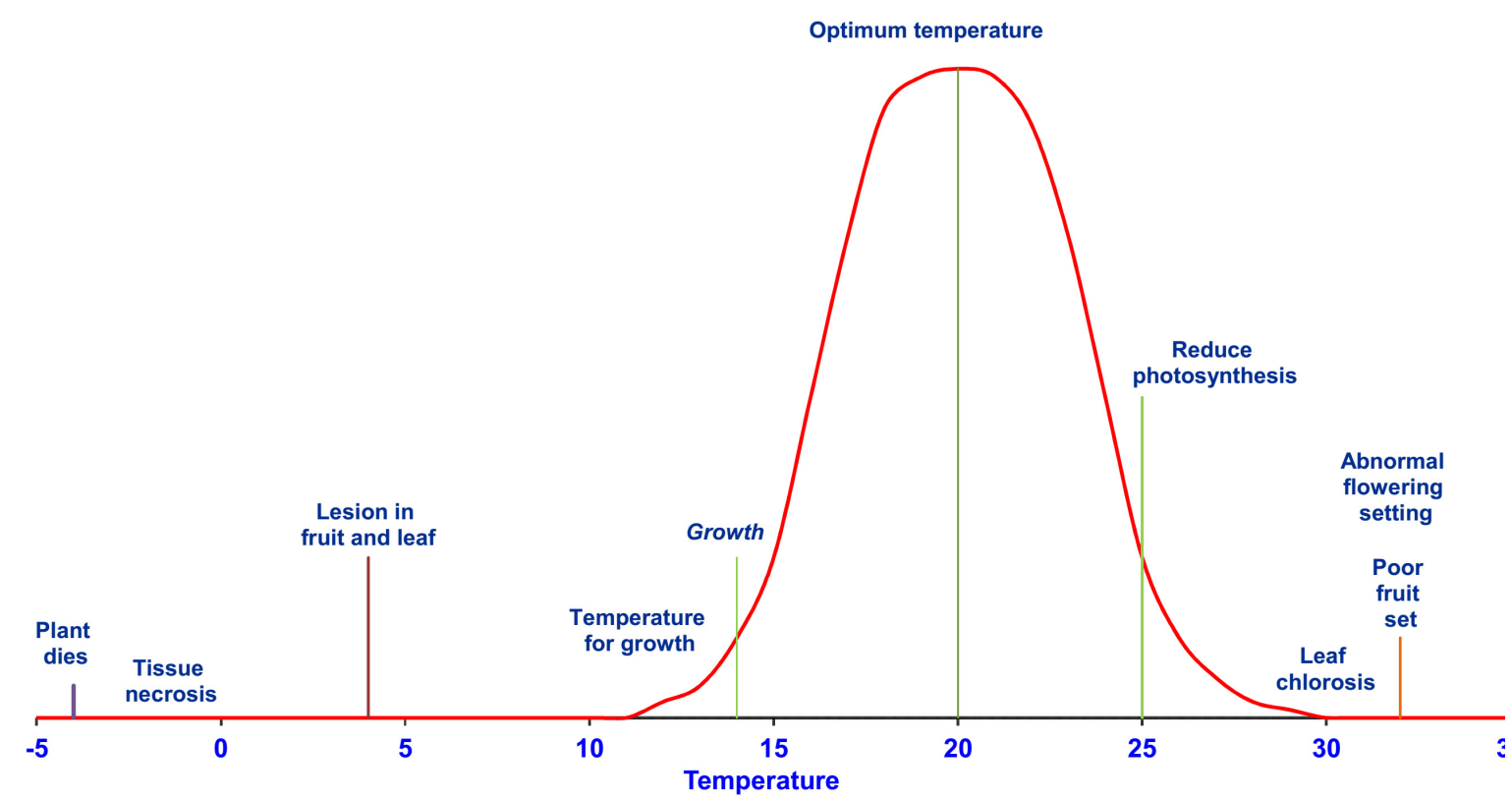

Figure 7: Growing phase of coffee and role of temperature drawn based on available literature (Bittenbender and Smith 1914; Descroix and Snoeck 2004; Rodríguez et al. 2011). 


\section{Two crops, agro-ecological zone and bioclimate}

\section{Two crops}

Farming information from different sources such as published literature, reports, news, district profiles, statistical reports, and field staff were documented. Based on the documented information, a quick survey was conducted in several districts to compile ground data on crop plantation. Most part of the survey was conducted along the places located close to the road because the road network is essential for market access. All kinds of plantations from small-scale to commercial were recorded. Thus the compiled geo-referenced data set was used as input for the suitability modelling. The location data set was plotted as a grid in a map to show the spatial distribution. Banana cultivation occurred mostly in the southern lowlands and to a lesser extent in inner valleys and hills toward the north (Fig. 8a). Coffee cultivation occurred mostly in the hilly regions in central Nepal (Fig. 8b).

Most banana plantations overlap with agricultural zones, with a few occurring in zones with other land use types (Fig. 8a). Coffee occupies a small portion of the agricultural landscape; plantations remain in the forest margins and other landscapes (Fig. 8b).

\section{Environmental stratification}

The Global Environmental Stratification (Metzger et al, 2013) is a statistical classification of the world's land surface into homogeneous bioclimatic strata facilitated by high-resolution global climate data sets. This system classifies the worlds' land surface into 125 bioclimatic strata (GEnS), which are aggregated into 18 zones (GEnZ). This statistically-based approach has considerable advantages over earlier global attempts at bioclimatic or ecosystems mapping (Zomer et al 2014). In Nepal, this classification corresponds well with the existing agro-ecological zones, partly due to the strong altitudinal zonation. A total of 11 Zones (Table 1) and 46 strata were identified inside Nepal. Percentage of each zone detected in Nepal for the baseline (2000) condition and changes in the future (2050) compared to baseline condition were presented in Table 1.

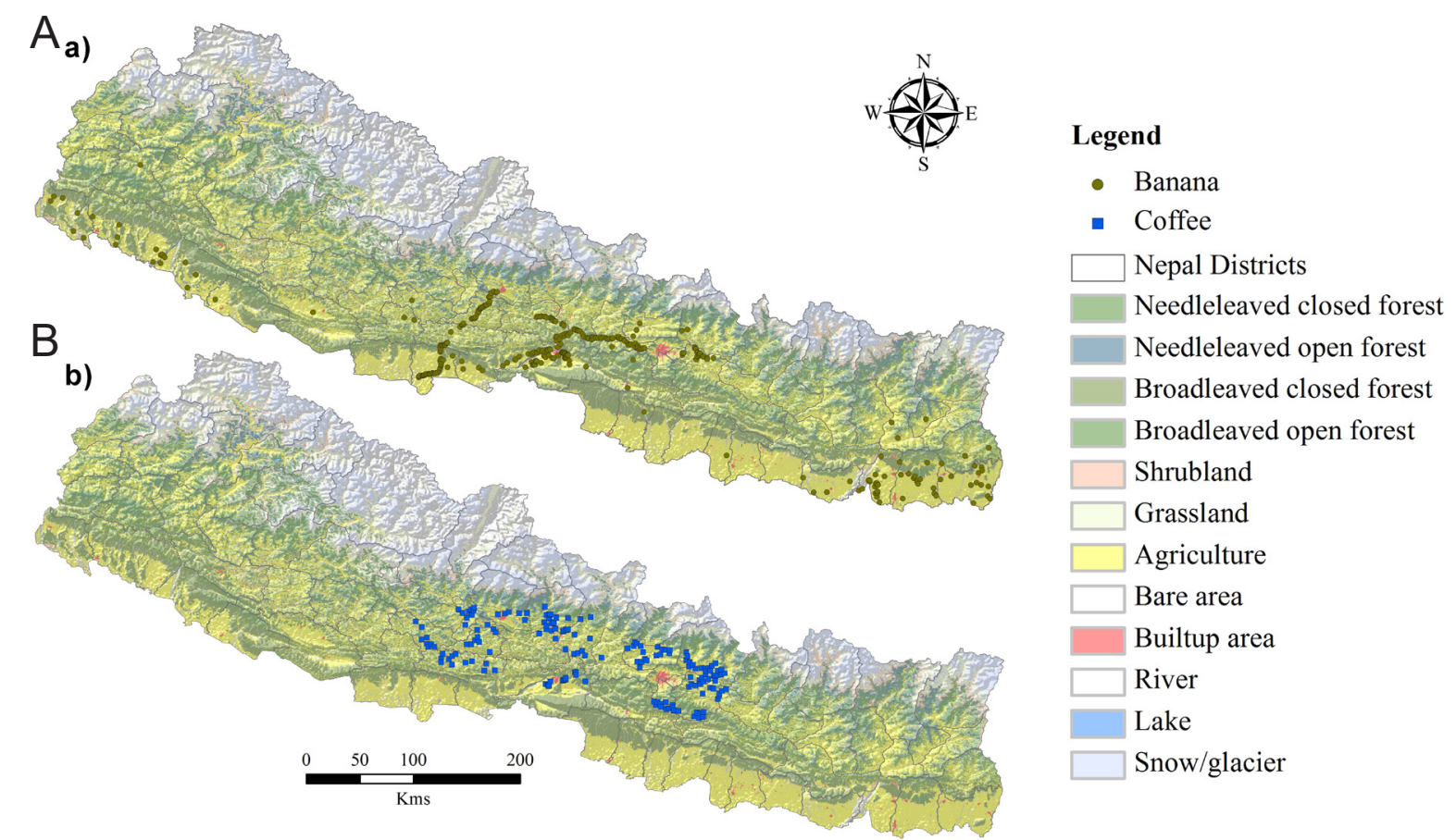

Figure 8: Zones suitable for (a) banana production and (b) coffee production both overlay with zones where agriculture is the dominant land cover. 
Suitable bioclimatic zones for banana were found occurring in three GEnZ, namely 'Hot and mesic', 'Hot and dry', and 'Extremely hot and moist', while coffee was found occurring in 'Hot and mesic', and 'Warm temperate and mesic' zones (Fig. 9). At present, 18 strata within three GEnZ were suitable for banana while 17 strata in two GEnZ were suitable for coffee. Banana was widely represented each GEnS while coffee was found in small patches of various strata. Both crops overlap in some of the strata in the 'Hot and Mesic' zone (see Fig. 9). The change in strata will affect the suitability for the crops.

The change in distribution of the bioclimatic zones (GEnZ) is detected in future climate change scenarios as modelled by an ensemble of 19 Earth System Models (Zomer et al 2014; Zomer et al 2015) provided by the Coupled Model Inter-comparison Project—Phase 5 (CIMP5). Significant change in bioclimatic zone was detected, such as about $60-70 \%$ reduction in the 'extremely cold and wet' and 'cold and wet' zones. The invasion of a new zone 'extremely hot and xeric' was detected (Table 1). Other zones, too, suffered noticeable change. These changes will have significant impact on the agro-ecological zone which will ultimately impact the crop production, as in the case with rubber plantations reported by Zomer et al (2014) in Xishuangbanna prefecture, Yunnan, China. Change in bioclimatic zones such as the 'Hot and mesic' (expansion), 'Hot and dry' (reduction), 'Extremely hot and moist' (expansion), and 'Warm temperate and mesic' (reduction) will have direct impact on banana and coffee. Furthermore, the CIMP5 scenarios show invasion of new zones in some part of lowland Nepal.

\section{Bioclimatic factors}

We used the environmental stratification zones (Fig. 9) along with other least correlated bioclimatic variables (http://www.worldclim.org/) to examine the potential distribution of two major crop species based on the theory of ecological niche modelling (ENM). The final sub-set of bioclimatic variables was selected based on iterative calculations of VIF (Rogerson 2001; Ranjitkar et al 2014b; Ranjitkar et al 2014a), where variance inflation factors (VIF) $<10$ were retained (Table 2). In addition to environmental stratification, model calibration was conducted using unchanging physical variables such as aspect, slope and several least correlated bioclimatic variables. Land use / land cover (LULC; Fig. 8), treated as a dummy variable, was used as a limiting factor in the distribution model.

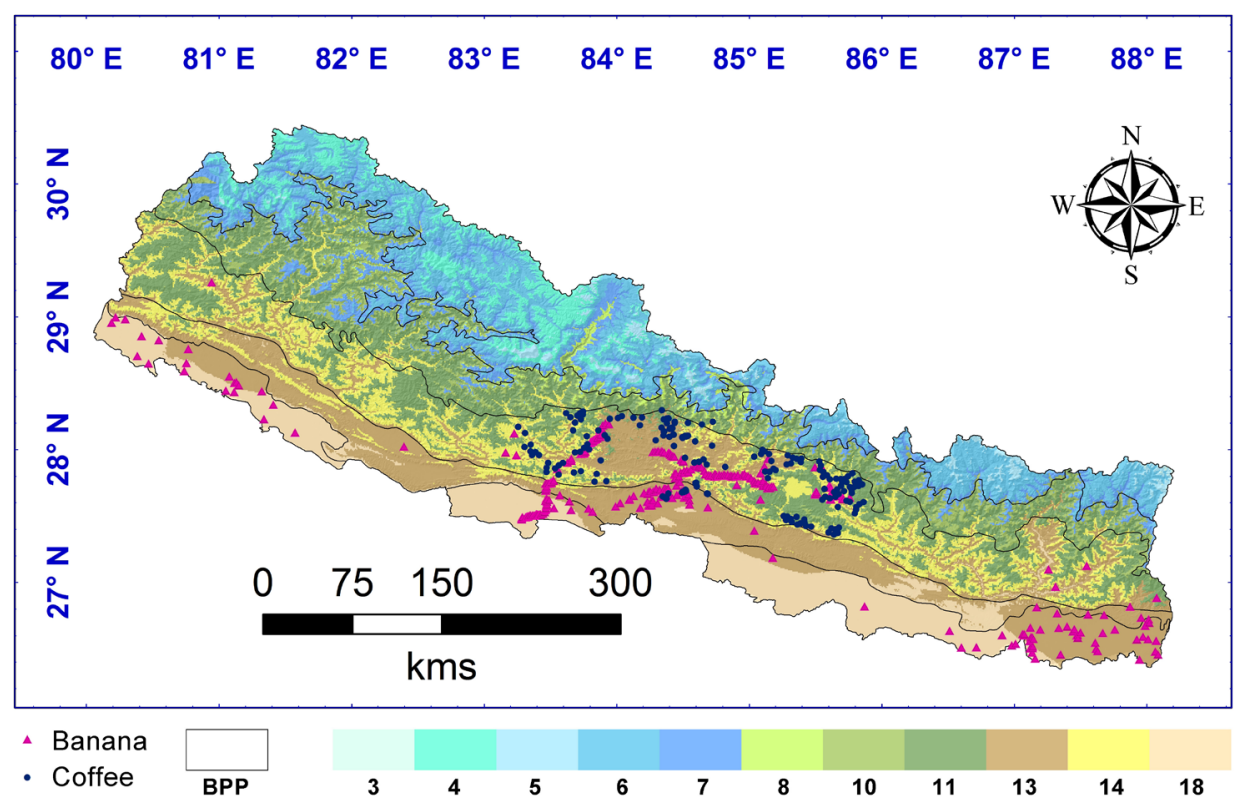

Figure 9: Bioclimatic zones (based on GEnZ) in Nepal and plantation sites of two cash crops; (GEnZ colour code see Table 5). 


\begin{tabular}{|c|c|c|c|c|c|c|}
\hline $\mathrm{Sn}$ & $\begin{array}{l}\text { Broad } \\
\text { biome }\end{array}$ & GEnZ & $\begin{array}{l}\text { Abb } \\
(\text { code*) }\end{array}$ & Lillesø (BPP) & Current $\%$ & $\begin{array}{l}\text { Change in } \\
\text { future } \%\end{array}$ \\
\hline 1 & Alpine & Extremely cold and wet 1 & ECW1 (3) & $\mathrm{Al}(\mathrm{Al} / \mathrm{Sa})$ & 0.04 & -71.39 \\
\hline 2 & Alpine & Extremely cold and wet 2 & ECW2 (4) & $\mathrm{Al} / \mathrm{TH}(\mathrm{Al} / \mathrm{Sa})$ & 4.29 & -60.92 \\
\hline 3 & Alpine & Cold and wet & CW (5) & $\mathrm{Al}(\mathrm{Al} / \mathrm{Sa})$ & 1.33 & -69.35 \\
\hline 4 & Alpine & Extremely cold and mesic & ECM (6) & $\mathrm{Al} / \mathrm{Sa}(\mathrm{Al} / \mathrm{Sa})$ & 13.17 & -4.64 \\
\hline 5 & Alpine & Cold and mesic & $\mathrm{CM}(7)$ & $\mathrm{Sa}(\mathrm{Al} / \mathrm{Sa})$ & 7.60 & 10.76 \\
\hline 6 & $\begin{array}{l}\text { Cool } \\
\text { temperate }\end{array}$ & Cool temperate and dry & CTD (8) & $\mathrm{Te}(\mathrm{Te} / \mathrm{St})$ & 1.41 & -13.12 \\
\hline 7 & $\begin{array}{l}\text { Cool } \\
\text { temperate }\end{array}$ & Cool temperate and moist & CTM (10) & $\mathrm{Te}(\mathrm{Te} / \mathrm{St})$ & 5.92 & -18.06 \\
\hline 8 & $\begin{array}{l}\text { Warm } \\
\text { temperate }\end{array}$ & Warm temperate and mesic & WTM (11) & $\mathrm{Te}(\mathrm{Te} / \mathrm{St})$ & 20.11 & -9.38 \\
\hline 9 & Sub-tropical & Hot and mesic & HM (13) & Sub-tropical $(\mathrm{Te} / \mathrm{St})$ & 22.18 & 31.48 \\
\hline 10 & Drylands & Hot and dry & HD (14) & $\begin{array}{l}\text { Sub-tropical/ Upper } \\
\text { tropical (Tr) }\end{array}$ & 13.00 & -23.12 \\
\hline 11 & Drylands & Extremely hot and xeric & EHX (17) & Lower tropical (Tr) & 0.00 & 100.00 \\
\hline 12 & Tropical & Extremely hot and moist & EHM (18) & Lower tropical (Tr) & 10.95 & 12.06 \\
\hline
\end{tabular}

Abb: Abbreviation; Al: Alpine, TH: Trans-Himalayan, Sa: Sub-alpine, Te: Temperate, St: Sub-tropical and Tr: Tropical; Lillesø: based on Lillesø et al (2005); BPP: Biodiversity profile project (1995)

Table 1: Global environmental zones identified for Nepal

\begin{tabular}{|l|l|l|l|l|l|l|l|l|}
\hline Crop & AI & bio2 & bio3 & bio14 & bio15 & bio18 & bio19 & pet_sum \\
\hline Banana & 8.58 & 3.21 & 3.66 & 2.11 & 7.39 & 9.58 & & 3.44 \\
\hline Coffee & 3.86 & 1.73 & 6.38 & 3.98 & 2.46 & & 2.36 & 2.66 \\
\hline
\end{tabular}

AI - Aridity index, bio2 - Mean Diurnal temperature, bio3 - Isothermality, bio14 - Precipitation of Driest month, bio15 - Precipitation seasonality, bio18 - Precipitation of Warmest Quarter, bio19 - Precipitation of Coldest Quarter, pet_sum Potential evapo-transpiration for summer months

Table 2: Bioclimatic factors with VIF $<10$ retained for further analysis

\begin{tabular}{|l|l|l|l|l|l|l|l|l|}
\hline \multicolumn{1}{|c|}{ Bioclimate } & & & & & \\
Crop & AI & bio2 & bio3 & bio14 & bio15 & bio18 & bio19 & Pet sum \\
\hline Banana & 6.80 & -2.88 & -2.58 & -17.92 & 3.84 & -25.42 & & 0.69 \\
& \pm 1.38 & \pm 0.50 & \pm 0.14 & \pm 8.62 & \pm 0.75 & \pm 8.76 & & \pm 0.47 \\
\hline Coffee & 5.84 & -3.05 & -2.50 & -10.68 & 4.66 & & -29.01 & 0.86 \\
& \pm 1.61 & \pm 0.42 & \pm 0.34 & \pm 9.95 & \pm 1.03 & & \pm 4.38 & \pm 0.48 \\
\hline
\end{tabular}

Negative values indicate a decrease compared to baseline and values prefixed with \pm indicate standard deviation from the average of four RCP scenarios.

Table 3: Changes in the average RCP scenarios compared to baseline in percentage 
In the area east of the Arun Valley, the rainy days including the monsoon and localized rains attain 160 days in a year in comparison to 90 days in West Nepal, which is west of the Kaligandaki gorge. The area west of the Arun Valley $\left(\sim 86^{\circ} 00^{\prime}\right)$ and east of the Kaligandaki gorge $\left(\sim 83^{\circ} 60^{\prime}\right)$ is central Nepal. Because of significant variation in the number of rainy days, wetness gradually decreases from east to west Nepal, which is an important factor affecting floral composition, vegetation as well as crops. This is the basis of floristic region classification (Stainton 1972). This classification system was used to determine bioclimatic variation in the banana and coffee growing regions, where these bioclimatic factors show variation that determine climatic suitability of the crop (Fig. 10).

The change in the bioclimatic factors (listed in Table 2) is detected in future climate change scenarios. Average results from all the RCPs show a very similar pattern of changes across all the

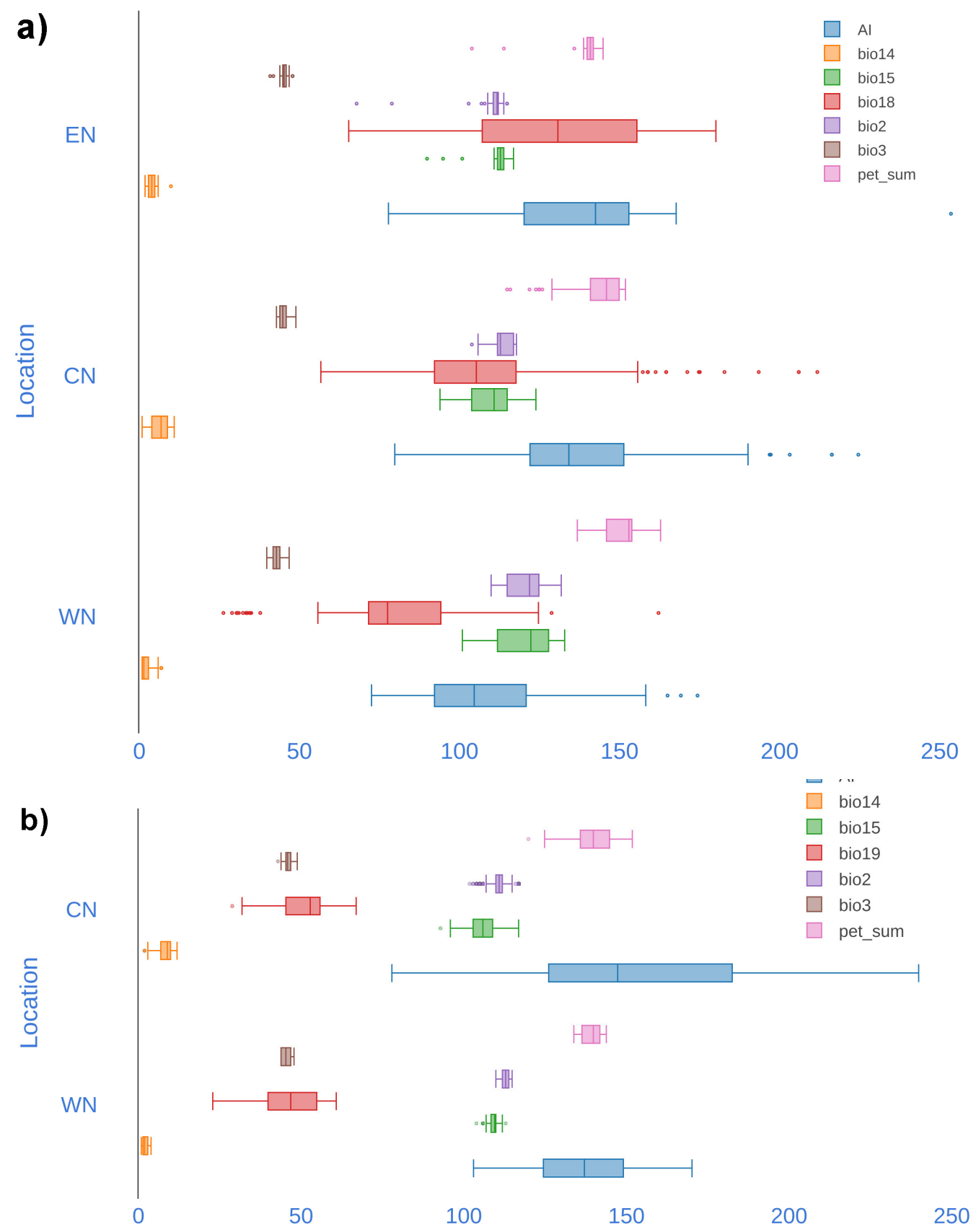

Figure 10: Bioclimatic range in current production zones of a) banana and b) coffee in Nepal; units for bioclimatic variables are $A I=\times 100$, bio $2={ }^{\circ} \mathrm{C} \times 10$, bio3 $=$ percent, bio14 $=\mathrm{mm}$, bio15 $=$ percent, bio18 $=\mathrm{mm} / 10$, bio19 $=\mathrm{mm}$, and pet_sum $=\mathrm{mm} / \mathrm{month}$. 
variables in the plantation zones of banana and coffee (Table 3). The future climatic data extracted for banana and coffee plantation sites show a good correspondence among each of the four RCPs examined in this study. (Figs. 11 and 12).

The Aridity Index (AI) rises at plantation sites for both crops, indicating slightly higher humid conditions in plantation sites by 2050. A higher AI represents more humid conditions and a lower AI means higher aridity (Zomer et al 2008). The aridity index exhibits very little variation across all four RCPs in the banana plantation zone (Figs. $11 \mathrm{AI}$ and $12 \mathrm{AI}$ ), reflecting general agreement among the RCP scenarios. The difference between baseline and RCP scenarios are higher in the western part of the plantation zone, while difference are less strong toward the east (Figs. $11 \mathrm{AI}$ and $12 \mathrm{AI}$ ).

The difference between baseline and projected mean diurnal temperature range (four RCPs 2050) shows a decrease in temperature by $2.8 \%$ in banana and by $3 \%$ in coffee plantation sites (Table 3 ). A decrease in diurnal temperature (bio2) indicates minimal difference between maximum temperature and minimum temperature in the future scenarios, probably because of the rise in monthly minimum temperature. In the plantation sites for both crops, across all the RCPs, bio2 exhibits a smaller difference (Table 3 and Figs. 11 bio2 and 12 bio2). Isothermality (bio3), which quantifies the amplitude of day-to-night temperature oscillations relative to the summer-to-winter temperature oscillation, is decreasing in both banana and coffee plantation sites (Table 3). Change in bio3 is larger in western Nepal compared to eastern Nepal in the banana plantation sites (Fig. 11 bio3), while it is consistent in coffee plantation sites (Fig. 12 bio3). The decrease in bio3 indicates a rise in night as well as winter temperature, which make the temperature oscillation minimal. In the banana plantation sites, isothermality (bio3) is consistent across all the RCPs but variation is comparatively higher in coffee plantation sites (Table 3).

Projected mean precipitation of the driest month (bio14) exhibits wide gaps between the four RCPs (Table 3), particularly in eastern and central Nepal (Figs. 11 bio14 and 12 bio14). On average, the bio14 in banana plantation sites shows a decrease of $17.92 \%$ for all RCPs, while the decrease is $10.68 \%$ for coffee plantation sites (Table 3). In the established plantation sites, this variable might not have much impact but it can influence the crops' potential ranges. Crop suitability can be strongly influenced by variability in precipitation. Precipitation seasonality (bio15) across all RCPs shows an increase in the seasonality in plantation sites for both crops (Table 3). A future shift in seasonality is more or less similar in east, central and west Nepal (Fig. 11 bio15 and 12bio15).

Projected mean precipitation of the warmest quarter (bio18) exhibited a wide gap between the four RCPs (Table 3), particularly in western and central Nepal (Fig. 11 bio18). On average, the bio18 in banana plantation sites shows a decrease of $25.42 \%$ for all RCPs (Table 3). Compared to western and central Nepal, future (2050) change in bio18 at banana plantation sites in eastern Nepal is much less strong and more consistent across all RCPs (Fig. 11 bio18). Precipitation of the coldest quarter (bio19), which is important for the distribution of coffee, exhibits some consistency between all four RCPs. On average, the bio19 in coffee plantation sites shows a decrease of $29.01 \%$ for all RCPs (Table 3). Future change in bio19 at coffee plantation sites in western Nepal is comparatively higher than that in the eastern part of central Nepal (Fig. 12 bio19). Potential evapotranspiration (PET) is one of important factors that affect crop production. In this study, we found PET during summer months (pet_sum) to be an important factor in the climatic suitability distribution of both crops. On average, an increase in pet_sum is detected in the plantation sites of both crops: $0.69 \%$ in banana plantation sites, and $0.86 \%$ in coffee plantation sites (Table 3). Future change in pet_sum for all the recorded plantation sites of both crops are consistent between all RCPs (Figs. 11 pet_sum and 12 pet_sum). 

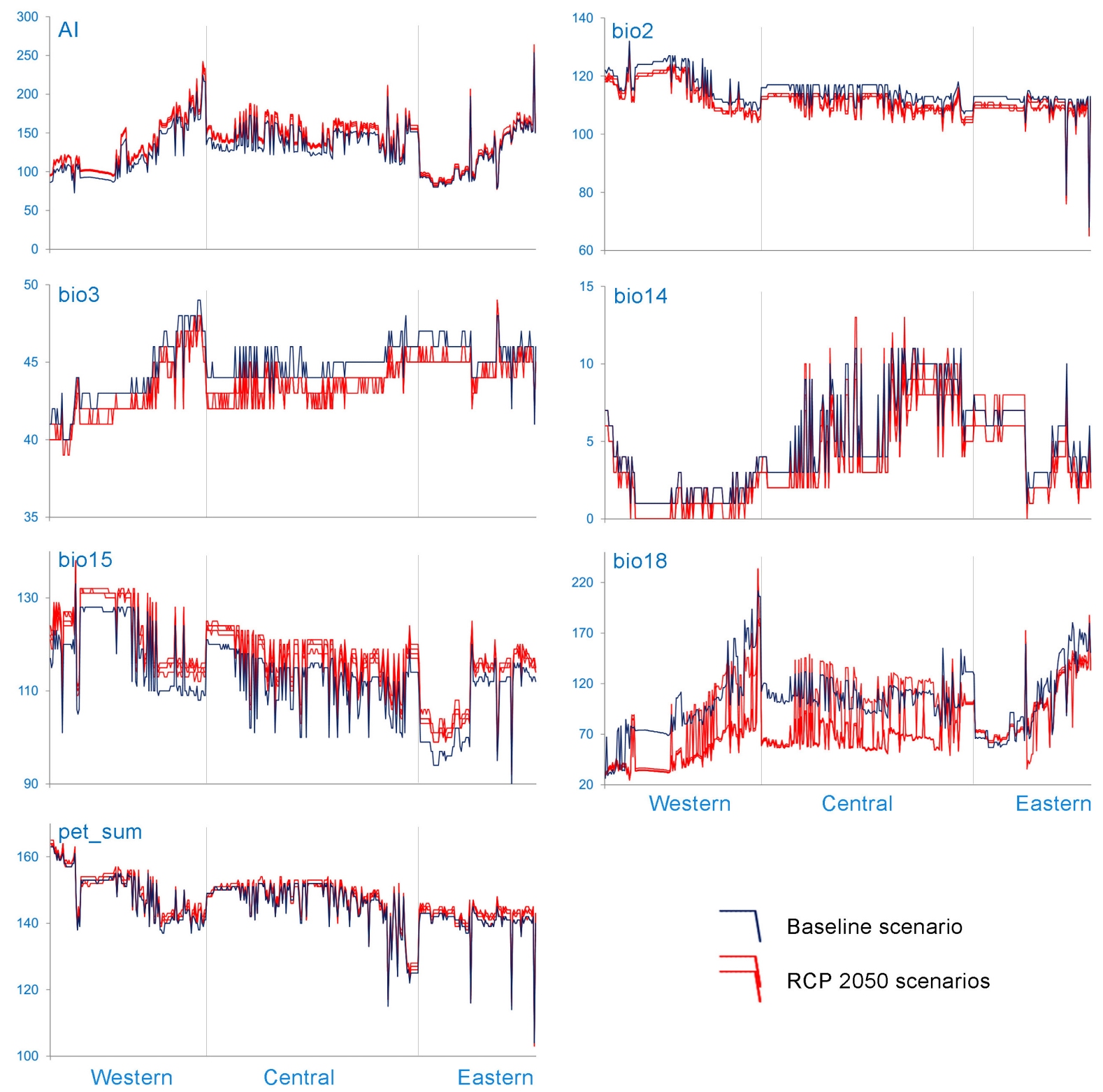

Figure 11: Bioclimatic range in current production zones of a) banana and b) coffee in Nepal; units for bioclimatic variables are $A I=\times 100$, bio $2={ }^{\circ} \mathrm{C} \times 10$, bio3 $=$ percent, bio14 $=\mathrm{mm}$, bio15 $=$ percent, bio18 $=\mathrm{mm} / 10$, and pet_sum $=\mathrm{mm} / \mathrm{month}$. 


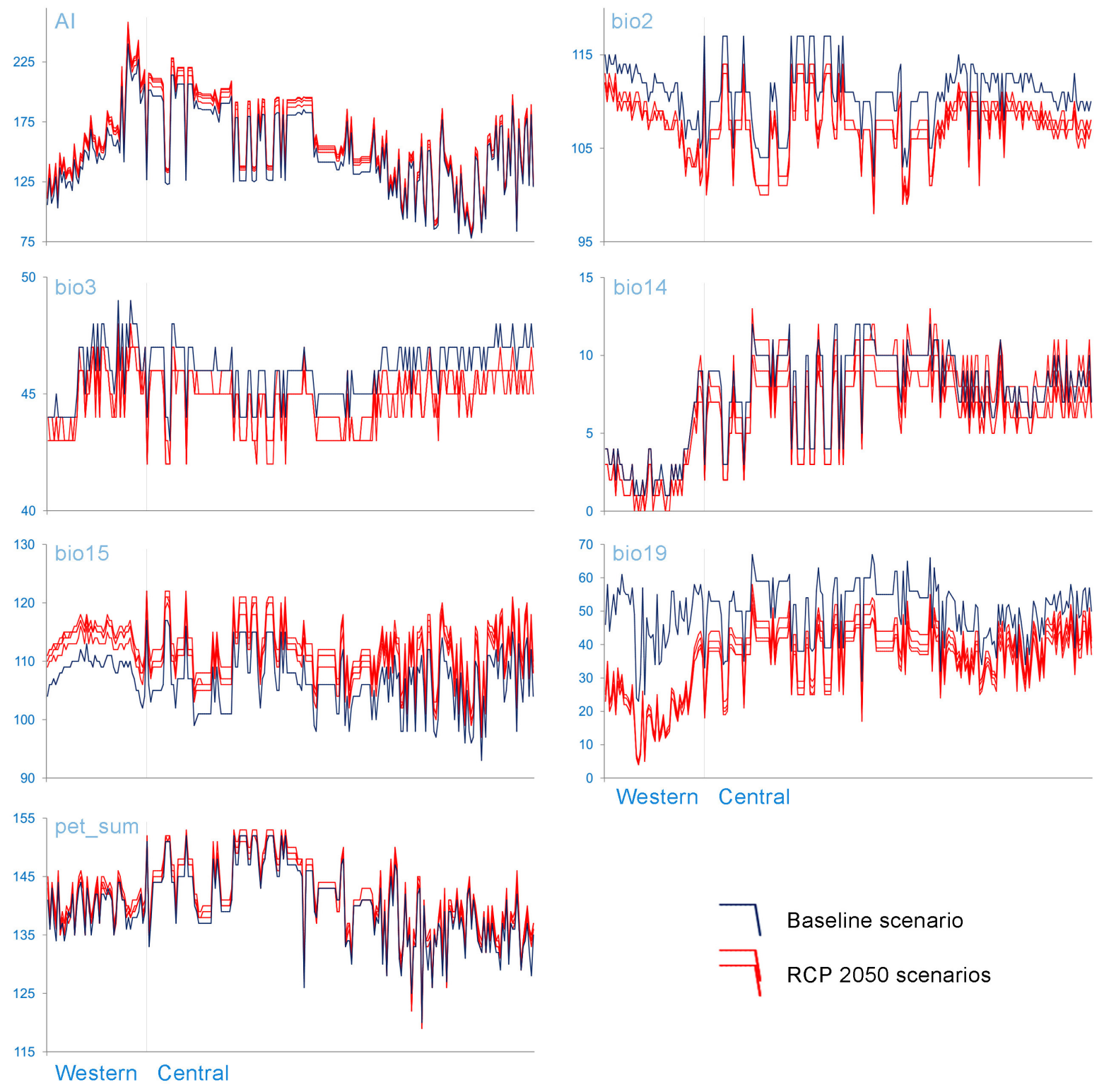

Figure 12: Bioclimatic range in current production zones of a) banana and b) coffee in Nepal; units for bioclimatic variables are $A I=\times 100$, bio $2={ }^{\circ} \mathrm{C} \times 10$, bio3 $=$ percent, bio14 $=\mathrm{mm}$, bio15 $=$ percent, bio19 $=\mathrm{mm}$, and pet_sum $=\mathrm{mm} / \mathrm{month}$. 


\section{Climate and suitability}

\section{Suitability of two crops in Nepal}

The current suitability of banana and coffee in Nepal, together with suitability changes in the future (2050) is shown in Figure 13. The methodology is briefly explained in this section, which is adopted from the published literature (e.g. Ranjitkar et al 2014b; Ranjitkar et al 2014a). The baseline climate was estimated using climate data for current the condition (1950-2000) from the WorldClim (www. worldclim.org) and CGIAR databases (www.csi.cgiar.org). The future climate (2050) from the WorldClim database was estimated using a downscaled ensemble $(n=63)$ of CIMP5 models (Taylor et al 2012) applied across four RCPs. The package BiodiversityR in the R programming language (Kindt, 2014) was used for generating crop suitability models. The sub-set of variables with $\mathrm{VIF}<10$ (Table 2) was selected for the suitability forecast. The raster layer, representing the climatic suitability for each crop, was reclassified based on the probability of occurrence of each crop, and the final distribution map was prepared.

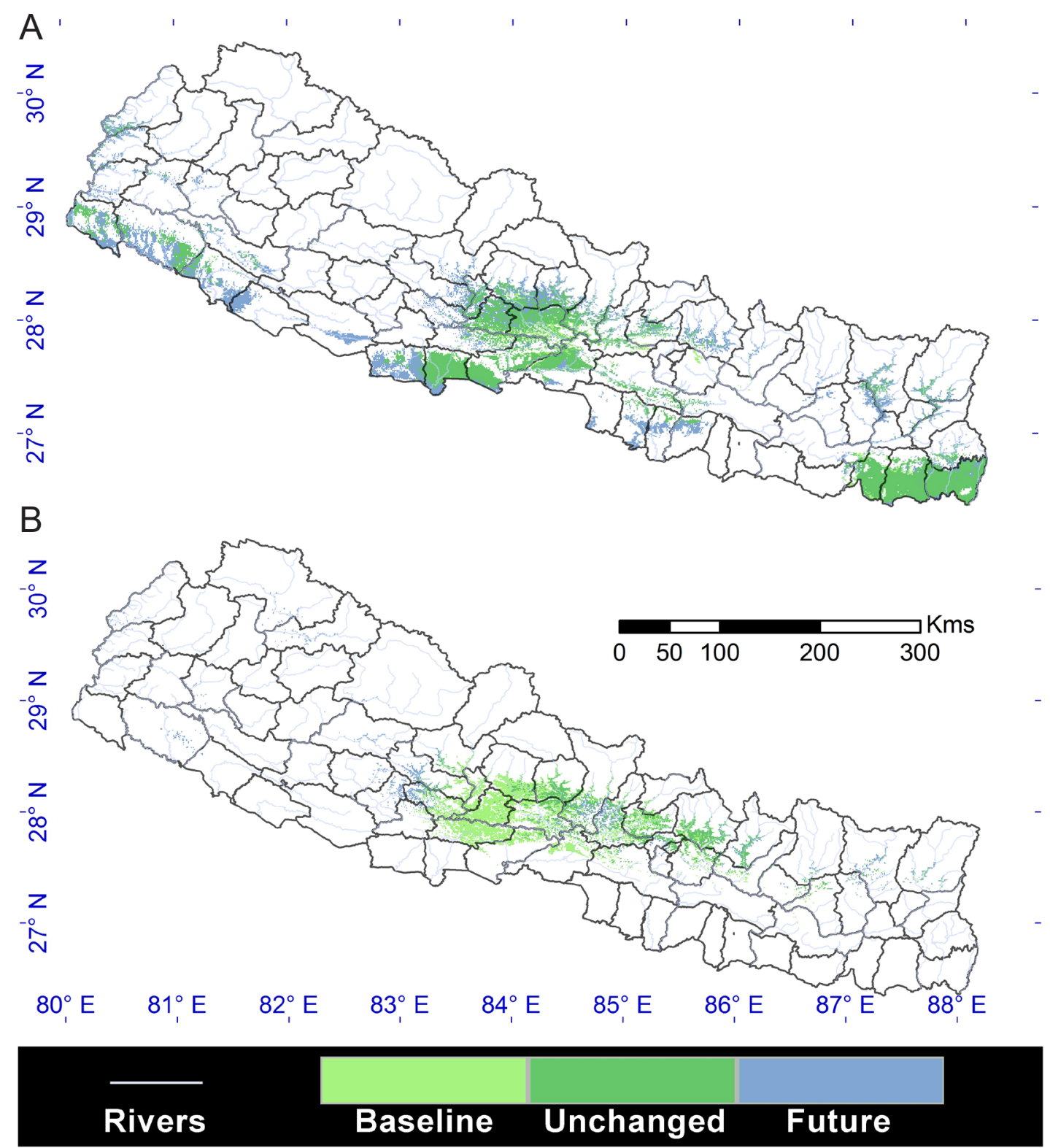

Figure 13: Predicted suitability for a) banana and b) coffee producing areas in Nepal: baseline (1950-2000) and average of RPC scenarios in 2050. 
Figure 13a illustrates banana suitability, which is mostly confined to the southern lower belt of Nepal (green colour in the figure), while some suitable areas were found along river valleys in the northern part of the country. Figure 13b illustrates coffee suitability confined to the central belt in central and western Nepal. If nothing changes and crop variety and production systems stay the way they are, then the current suitable areas for the crop will change by 2050. Banana suitability will be retained in most current suitable areas by 2050 (dark green), reduced in some places (light green), and expanded in larger new areas (Fig. 13a). Figure 13b illustrates a drastic decline in coffee suitability by 2050. Coffee suitability will be retained in some places by 2050 (dark green), reduced in most places (light green), and expanded in others (blue).

Overall, there are positive changes in banana suitability in the lowlands, including lower elevation areas in the mid-hills. Because of its short lifespan, banana is more resilient to climate change. In contrast, coffee has a long lifespan ranging from 30 to 50 years. Therefore, the possible impact of future climates is a major concern for the crop. As one of possible measures to reduce the impact of climate change on coffee, intercropping with banana was recommended. Research has shown that shade can reduce the temperature in the understory plants by up to $2^{\circ} \mathrm{C}$ or more (Jassogne et al 2013). In addition, banana yields were reported to be higher in coffee-banana systems compared to monocropping (van Asten et al 2011). In Nepal, about $23 \%$ of current coffee-suitable zones overlap with the predicted suitable zone for banana in the future, which are potential sites for such intercropping.

\section{Productivity survey}

A productivity survey was carried out in two districts for each crop using a structured questionnaire. During the survey, general questions were asked about the selected crop systems of the area, the influence of climate and existing inter-cropping practices. From existing growers, inputs and information on production-related issues were accessed where possible. In addition, soil properties at the plantation site were accessed to assess the soil condition at the growing sites of both crops. The criteria developed by the Nepal Agricultural Research Council (NARC) was followed (Table 4) to understand the condition of soil fertility in the plantation site (Pun et al 2014; Dawadi and Thapa 2015).

\begin{tabular}{|l|l|l|l|l|}
\hline Nutrient status & $\begin{array}{l}\text { Soil organic matter } \\
(\%)\end{array}$ & Total N (\%) & $\begin{array}{l}\text { Available } \mathrm{P}_{2} \mathrm{O}_{5}(\mathrm{~kg} \\
\text { ha-1) }\end{array}$ & $\begin{array}{l}\text { Available } \mathrm{K}_{2} \mathrm{O}(\mathrm{kg} \\
\text { ha-1 })\end{array}$ \\
\hline Very low & $<1.0$ & $<0.05$ & $<10$ & $<55$ \\
\hline Low & $1.0-2.5$ & $0.05-0.1$ & $10-30$ & $55-110$ \\
\hline Medium & $2.5-5.0$ & $0.1-0.2$ & $30-55$ & $110-280$ \\
\hline High & $5.0-10.0$ & $0.2-0.4$ & $55-110$ & $280-500$ \\
\hline Very high & $>10.0$ & $>0.4$ & $>110$ & $>500$ \\
\hline
\end{tabular}

Table 4: Condition of soil fertility in Nepal. Source: Soil Science Division, NARC, Khumaltar, Lalitpur, Nepal 


\section{Banana}

Altogether 53 farmers (households) growing banana were interviewed in Kavrepalanchok and 52 farmers (households) in Chitwan. In Kavrepalanchok, farmers grew widely divergent varieties of banana but on a small scale. Banana was found mixed with other crops in cropland. In Chitwan, farmers grew few varieties of banana on comparatively larger land. The farmers had generally adopted crop rotation technique, where banana was grown for 5-6 years and then cleared. Rice, maize and mustard are grown for a year or two before re-planting banana on the same land. This is done generally to minimize insect and disease infestation. From a climate point of view, most parts of Chitwan district were found suitable for banana plantation, where banana yields are comparatively higher as shown by the yield data over several years (MOAD 2013). This provides farmers with an opportunity to safely convert their subsistence farming into commercial banana plantations. In addition, farmers are also learning adaptation techniques to cope with immediately observed problems such as crop pests through crop rotation.

Soil nutrient content in the banana farming location was studied and compared, which revealed that banana plantation sites in Kavrepalanchok district contain lower soil organic matter (SOM) than in Chitwan. The SOM range in Chitwan was 0.95 to $5.96 \%$, whereas that of Kavrepalanchok is 0.61 to $4.17 \%$. The higher percentage of SOM in Chitwan compared to Kavrepalanchok is due to the timely and managed application of fertilizers in commercial banana farms. Bananas prefer slightly acidic to neutral soil with a $\mathrm{pH}$ range of 6-7.5. The soil $\mathrm{pH}$ status of banana farms in Chitwan (53.5\% of surveyed farms) are neutral. About $55.8 \%$ of banana farms in Kavrepalanchok are slightly acidic, which favours the expansion of banana plantations.

Banana needs a large amount of nitrogen, phosphorus and particularly potassium (Nelson et al 2006). Most of banana farms in Chitwan (72.1\%) have a medium nitrogen content, while very few have high or low contents. The soil nitrogen status of Kavrepalanchok is medium (51.2\%) to low $(37.2 \%)$. The available phosphorus status of both districts ranged from very low to high. The lab analysis report shows that $65.1 \%$ of banana farms in Chitwan contain a very high quantity of available phosphorus, whereas only $44.2 \%$ of banana farms in Kavrepalanchok have a very high

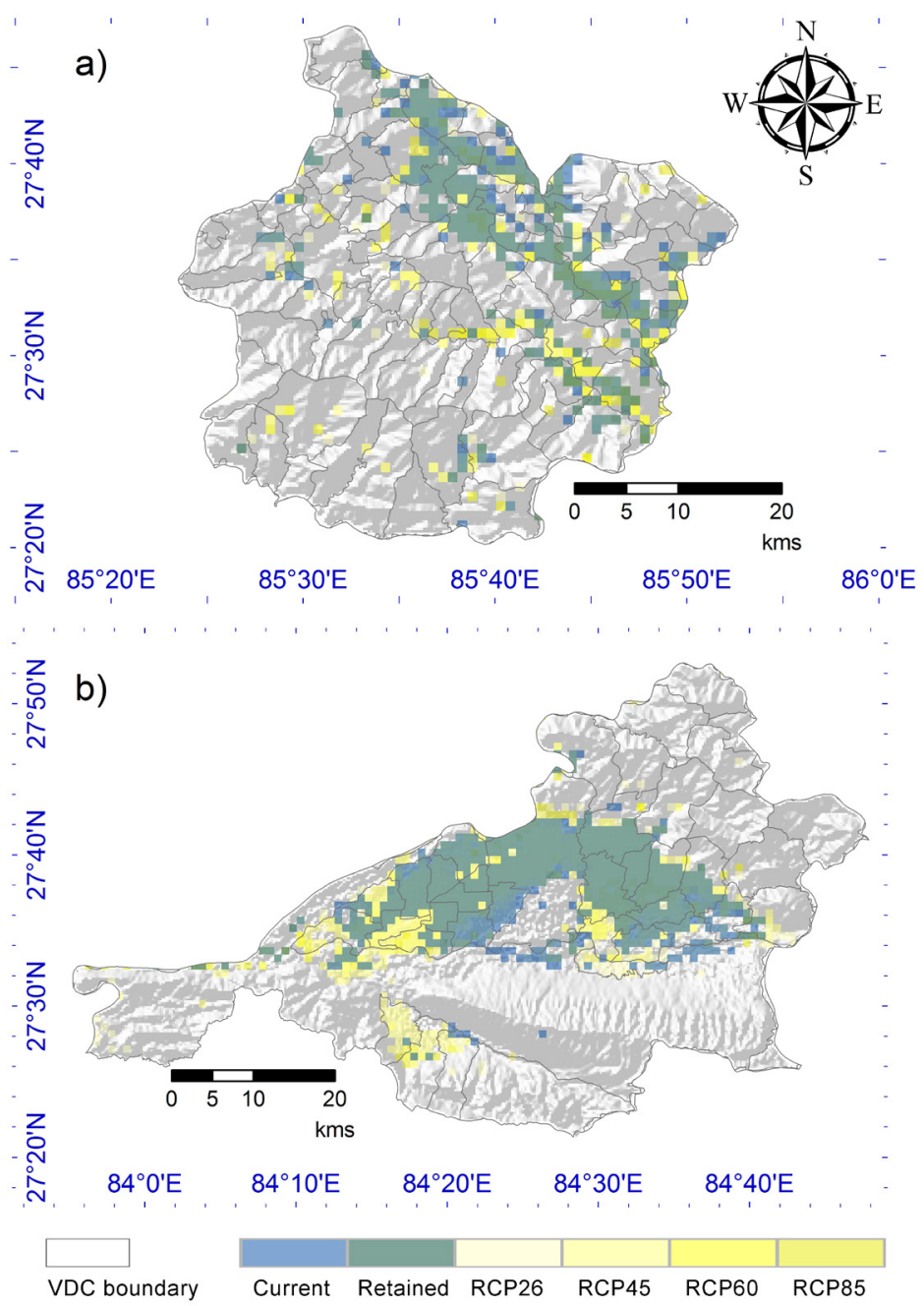

Figure 14: Suitability of banana in two districts: a) current and future situation in Kavrepalanchok, and b) current and future situation in Chitwan. The future situation includes the ensemble of four RCP scenarios. 
phosphorus content. Overall, the phosphorus content in the soil of both surveyed districts is suitable for banana plantations. The soil potassium of both of districts was not found limiting for banana production as early assumed. The soil potassium levels in plantation sites in Chitwan are low to high with a medium (55.8\%) potassium level in most sites. Compared to that, $39.5 \%$ of soil samples from banana farms in Kavrepalanchok show medium, and 25.6\% show a very high potassium content. Overall, the soil analysis suggests that the soil condition is very suitable for banana plantation in Chitwan district, whereas Kavrepalanchok has similar potential with regards to potassium content, however, there is a need to improve the soil nitrogen content. The planting of nitrogen-fixing trees could be very beneficial in the Kavrepalanchok district to enable commercial banana plantations.

Analysis revealed that climatic suitability for banana plantations will decline at the lower elevation sites (south and southwest part) and expand in higher elevation sites (north and northeast part) in Chitwan (Fig. 14a). In Kavrepalanchok district, climatic suitability for banana plantations will increase in the south, north as well as northeast parts (Fig. 14b). As in most parts of the country, the projected climatic conditions seem favourable for banana plantation in the study districts. In Chitwan district, already there is a huge commercial plantation of banana that could be continued in the future in most locations. Climatic suitability in Kavrepalanchok district will expand to some extent, and with improvement in soil nitrogen, many parts of this district will become suitable for commercial banana plantation. The analysis did not factor in potential crop pest problems, although the farmers' survey indicated that crop pests are a major problem, particularly in Chitwan, something which may become more severe under a warming climate.

\section{Coffee}

A total of 40 and 55 farmers (households) growing coffee were interviewed in Chitwan and Lamjung districts respectively. Coffee is an attractive crop because of its huge market potential, but understanding of its plantation and processing for marketing is narrower. Expanding export and internal market lead farmers to try planting coffee but they are struggling to achieve success. In Chitwan, a small number of farmers started planting coffee as a curious crop. Coffee was intercropped with cereal like buckwheat, fodder crops, banana, mango, turmeric, and even with ornamental plants. In yet other places it was grown as a mono-crop. The majority of Chitwan district is climatically not suitable for coffee production and most of the current coffee plantation areas are in at the fringes of their climatic comfort zones. Some hilly locations in the district are similar to other coffee-growing regions in Nepal, which might be why local organizations or farmers decided to grow coffee in this region.

In Lamjung district, coffee cultivation started in 2003 and is currently grown commercially, and as micro-scale farming. Coffee was grown at a low elevation of around $550 \mathrm{~m}$ in the district. Farmers grew coffee mostly intercropped with banana, citrus, ginger, turmeric, and in a few locations with millet. Coffee grown in almost all surveyed villages was organic. While old plantations of coffee were destroyed by the white stem borer, the problem was less severe in new plantations. The large area of Lamjung district was found climatically suitable for coffee cultivation, however, the total production of the district was could not compared to neighbouring districts (MOAD 2013).

Arabica coffee has particular soil requirements, but the crop can grow well on a wide range of soil types (Kuit et al 2004). According to Kuit et al (2004), in Vietnam — one of the top quality and quantity coffee-producing countries - coffee grows well on soils of volcanic origin, but also on granite-based soils and other soil types. While the soil type is of lower importance, the texture and 
structure are significant for the performance of the coffee. Ideally, the $\mathrm{pH}$ is between 4.5 and 6 , but neutral soil will also support plantations properly. Soil organic matter should be from 2 to $4 \%$.

Analysis of soil nutrient content in the coffee farm soil revealed $1.28 \%$ to $5.63 \%$ of SOM in two districts. The nitrogen content ranges from $0.09 \%$ to $0.35 \%$. Similarly, phosphorus ranges from 55 to $447 \mathrm{~kg} \mathrm{ha}^{-1}$, and the potassium content ranges from 71 to $566 \mathrm{~kg} \mathrm{ha}^{-1}$ at coffee plantation sites in two districts. Coffee needs various nutrients for optimal growth, fruit and root development and for resistance to pests and diseases. Nutrients accumulated in the fruits will be removed when the berries are harvested. Coffee needs a large amount of nitrogen, phosphorus and potassium during the different phases of its life cycle and phenology (Kuit et al 2004).

The climatic suitability of coffee is projected to decline in both districts (Figs. 15a and b) as is the case for the whole country. In Lamjung district, climatic suitability for coffee plantation is projected to remain the same in most of the currently suitable areas (Fig. 15a). Present coffee plantation areas in Chitwan district are in climatically less suitable zones, which are projected to decline in future (Fig. 15b). Coffee is not a suitable crop to promote in Chitwan district, but in Lamjung district, existing plantations can be properly maintained in different ways such as agroforestry systems, changing crop variety.

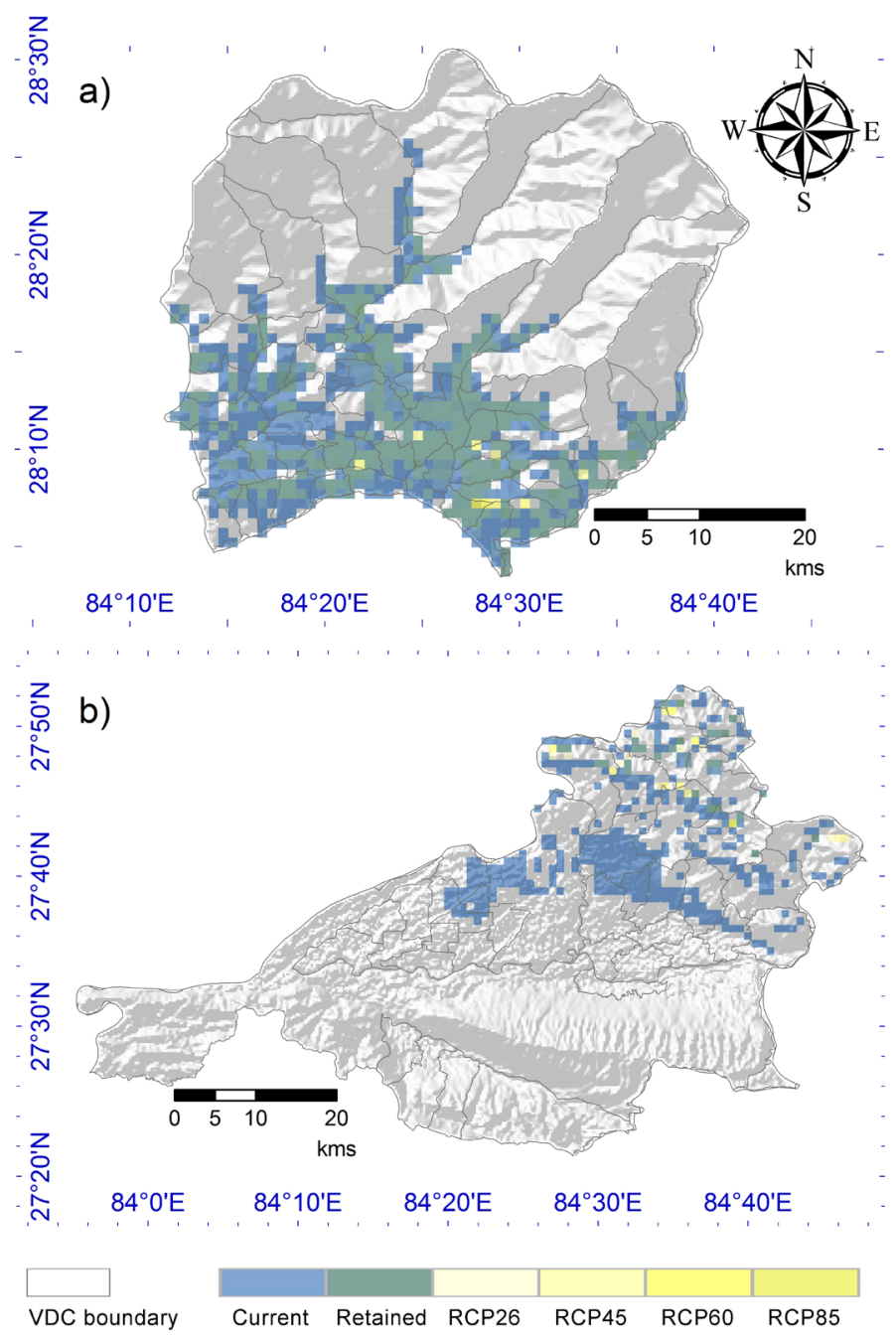

Figure 15: Suitability of coffee in two districts: a) current and future situation in Lamjung, and b) current and future situation in Chitwan; Future situation includes the ensemble of four RCP scenarios. 


\section{Conclusion and recommendations}

The spatial modelling of these two cash crops delineated the currently climatically suitable area for banana and coffee plantations in Nepal, and the projected potential areas available for expansion for these two crops by 2050. Future projection indicates that climatically suitable areas for banana will expand in the future with good potential for increasing banana production. For coffee, the future climate it seems will not be as favourable as for banana. Substantial areas of current plantations will become less or even non-productive in the future, most likely due to higher temperatures. Climate change will make available new areas to coffee production, particularly in the mid-west and far-west regions of Nepal. However, there is indicated a need for serious concern for current production areas requiring an improved understanding of suitability, management and other adaptation approaches.

Base on the case studies it is evident that smallholder farmers have differing views on the sustainability of banana and coffee plantations, however these were mainly concerned with market opportunities. The economics of banana are seen as better and many smallholder farmers from the surveyed districts were found to shift their subsistence farming practices to commercial banana cultivation, particularly in the lowlands. Farmers in the lowlands were found to be developing coping measures for cultivation problems such as pests. Such practices, as well as market opportunities for smallholder farmers in the mid-hill areas were found to be still lacking. These need to be promoted if banana is to become a viable cash crop in these regions. In the case of coffee, the lack of proper knowledge on cultivation, management, quality assurance and immediate market opportunities were found to be the main constraints for smallholder farmers. Farmers need support with proper training on soil preparation, coffee-based agroforestry practices, pest management, and notably, the selection of climatically and edaphically suitable sites for cultivation.

Based on the results from this study, we recommend the following strategy and policy points:

- The Agriculture Perspective Plan (Government of Nepal 1995), National Agriculture Policy (MOAC 2004) and Agribusiness Promotion Policy (MOAC 2006) highlighted diversification, modernization, commercialization and promotion of the agricultural sector for reducing poverty by providing employment opportunities and promoting the involvement of the private sector in the development of agriculture. To this end, it has prioritized various different crops for different ecological zones of the country including terai, mid-hills and high-hills. This corresponds to the theme of "the right crop in the right place", which is very important to assure high crop yields and benefits to farmers. The results from the spatial modelling can help with such selection. However, on-the-ground observation, including soil tests and the assessment of farmers' current best options remain essential.

- The lack of market opportunities for smallholder farmers seem to be one of the major problem at present, particularly for coffee. Marketing channels for selling Nepalese coffee in the international market directly by the coffee producer cooperatives are not well established. Personal contact of the traders rather than institutionalized exporting mechanism appears to be dominating the market value-chain of coffee that is exported in the international sector (Tiwari 2010). This leads to uncertainty of getting market and good prices of Nepalese coffee in the international market. It needs to be properly addressed through cooperatives or other such local bodies, including guaranteeing a correct price for the farmers. 
- There is a lack of knowledge on cash crop (particularly coffee) cultivation and suitable varieties among the farmers. This highlights the need for improved extension, proper training on commercial cash crop cultivation along with proper and appropriate management techniques.

- This research did not cover pest-related problems, which could be severe in the potential production zones under certain climate change scenarios. One recommendation, therefore, is to perform an in-depth study of crop pests and their possible future distribution. The spatial modelling technique is a frequently used method in projecting the future distribution of crop pests (Kutywayo et al 2013) and to identify the need to develop adaptation mechanisms.

- This research identified locations where coffee could be intercropped with banana. Evidence from experiences in the Latin America and the African Highlands indicate that such climate-smart systems are beneficial for both crops and smallholder farmers. In Nepal, too, some smallholder farmers are already reaping the benefits from these types of agroforestry approaches. Our results revealed suitable zones for coffee-banana systems; there could be other options which need to be studied spatially as well as on the ground. 


\section{References}

Battisti DS, Naylor RL (2009) Historical warnings of future food insecurity with unprecedented seasonal heat. Science (80- ) 323:240-244.

Bittenbender HC, Smith VE (1914) Growing coffee in Hawaii, Revised ed. College of Tropical Agriculture and Human Resources

Bunn C, Läderach P, Ovalle Rivera O, Kirschke D (2014) A bitter cup: climate change profile of global production of Arabica and Robusta coffee. Clim Change.

Davis AP, Gole TW, Baena S, Moat J (2012) The impact of climate change on indigenous Arabica coffee (Coffea arabica): predicting future trends and identifying priorities. PLoS One 7:e47981.

Dawadi DP, Thapa M (2015) Soil fertility status of Nepal: report from laboratory analysis of soil samples of five developmental regions. In: Karki KB, Tripathi BP, Manandhar R, et al (eds) Proc. Second Natl. Soil Fertil. Res. Work. 24-25 March, 2015. Soil Science Division, National Agriculture Research Institute (NARI), Nepal Agricultural Research Council (NARC), Khumaltar, Lalitpur, Nepal, pp 42-51

Descroix F, Snoeck J (2004) Environmental factors suitable for coffee cultivation. In: Wintgens JN (ed) Coffee growing, Process. Sustain. Prod. Wiley-VCH Verlag GmbH \& Co. KGaA, Weinheim, pp 164-177

Deuter P, White N, Putland D (2012) The case study of critical temperature thresholds for banana. Queensland

FAOSTAT (2015) FAO database. In: Food Agric. Organ. United Nations. http://faostat3.fao.org/ download/Q/QC/E. Accessed 20 May 2015

Frison EA, Escalant J V, Sharrock S (2004) The global Musa genomic consortium: a boost for banana improvement. In: Jain SM, Swennen R (eds) Banan. Improv. Cell. Mol. Biol. Induc. Mutat. Proc. a Meet. held Leuven, Belgium, 24-28 Sept. 2001. Science Publishers, Inc., pp 341-349

Hertel TW, Burke MB, Lobell DB (2010) The poverty implications of climate-induced crop yield changes by 2030. Glob Environ Chang 20:577-585.

Heslop-Harrison JS, Schwarzacher T (2007) Domestication, genomics and the future for banana. Ann Bot 100:1073-84.

Jassogne L, Läderach P, Asten P Van (2013) The impact of climate change on coffee in Uganda: Lessons from a case study in the Rwenzori Mountains.

Kindt R (2014) BiodiversityR: GUI for biodiversity, suitability and community ecology analysis.

Kuit M, Jasen DM, Van Thiet N (2004) Manual for Arabica cultivation. Tan LamAgricultural Product Joint Stock Company, Cam Lo, Quang Tri

Kutywayo D, Chemura A, Kusena W, et al (2013) The impact of climate change on the potential distribution of agricultural pests: the case of the coffee white stem borer (Monochamus leuconotus P.) in Zimbabwe. PLoS One 8:e73432.

Lillesø J-PB, Shrestha TB, Dhakal LP, et al (2005) The Map of Potential Vegetation of Nepal - a forestry/agro-ecological/biodiversity classifi cation system. Forest \& Landscape Development and Environment Series 2-2005 and CFC-TIS Document Series No.110

Lobell DB, Burke MB (2010) On the use of statistical models to predict crop yield responses to climate change. Agric For Meteorol 150:1443-1452.

Machovina B, Feeley KJ (2013) Climate change driven shifts in the extent and location of areas 
suitable for export banana production. Ecol Econ 95:83-95.

Metzger MJ, Bunce RGH, Jongman RHG, et al (2013) A high-resolution bioclimate map of the world: a unifying framework for global biodiversity research and monitoring. Glob Ecol Biogeogr 22:630-638.

MoAD (2013) Statistical information on Nepalese agriculture 2012/2013.

MoAD (2014) Statistical information on Nepalese agriculture 2013/2014.

Nelson SC, Ploetz RC, Kepler AK (2006) Musa species (bananas and plantains). Species profiles Pacific Isl Agrofor 33.

Nzeyimana I, Hartemink AE, Geissen V (2014) GIS-Based Multi-Criteria Analysis for Arabica Coffee Expansion in Rwanda. PLoS One 9:e107449.

Pun TB, Chalise B, Thapamagar D (2014) Soil fertility management for sustainable agriculture, 1st edn. Government of Nepal, Nepal Agricultural Research Council, Agricultural Research Centre, Kimugaun, Dailekh

Ranjitkar S, Kindt R, Sujakhu NM, et al (2014a) Separation of the bioclimatic spaces of Himalayan tree rhododendron species predicted by ensemble suitability models. Glob Ecol Conserv 1:2-12.

Ranjitkar S, Xu J, Shrestha KK, Kindt R (2014b) Ensemble forecast of climate suitability for the Trans-Himalayan Nyctaginaceae species. Ecol Modell 282:18-24.

Rodríguez D, Cure JR, Cotes JM, et al (2011) A coffee agroecosystem model: I. Growth and development of the coffee plant. Ecol Modell 222:3626-3639.

Rodríguez D, Cure JR, Gutierrez AP, et al (2013) A coffee agroecosystem model: II. Dynamics of coffee berry borer. Ecol Modell 248:203-214.

Rogerson PA (2001) Statistical methods for geography. London, Sage.

Roudier P, Sultan B, Quirion P, Berg A (2011) The impact of future climate change on West African crop yields: What does the recent literature say? Glob Environ Chang 21:1073-1083.

Stainton JDA (1972) Forests of Nepal. J. Murray, London

Taylor KE, Stouffer RJ, Meehl G a. (2012) An Overview of CMIP5 and the Experiment Design. Bull Am Meteorol Soc 93:485-498.

Van Asten PJA, Wairegi LWI, Mukasa D, Uringi NO (2011) Agronomic and economic benefits of coffee-banana intercropping in Uganda's smallholder farming systems. Agric Syst 104:326-334.

Waldmüller L (2012) Rural development Agriculture and climate change. 2.

Wintgens JN (2004) The coffee plant. In: Wintgens JN (ed) Coffee growing, Process. Sustain. Prod. Wiley-VCH Verlag GmbH \& Co. KGaA, Weinheim, pp 3-24

Zomer RJ, Trabucco A, Bossio D a., Verchot L V. (2008) Climate change mitigation: A spatial analysis of global land suitability for clean development mechanism afforestation and reforestation. Agric Ecosyst Environ 126:67-80.

Zomer RJ, Trabucco A, Wang M, et al (2014) Environmental stratification to model climate change impacts on biodiversity and rubber production in Xishuangbanna, Yunnan, China. Biol Conserv 170:264-273.

Zomer RJ, Xu J, Wang M, et al (2015) Projected impact of climate change on the effectiveness of the existing protected area network for biodiversity conservation within Yunnan Province, China. Biol Conserv 184:335-345. 
The World Agroforestry Centre is an autonomous, non-profit research organization whose vision is a rural transformation in the developing world as smallholder households increase their use of trees in agricultural landscapes to improve food security, nutrition, income, health, shelter, social cohesion, energy resources and environmental sustainability. The Centre generates science-based knowledge about the diverse roles that trees play in agricultural landscapes, and uses its research to advance policies and practices, and their implementation that benefit the poor and the environment. It aims to ensure that all this is achieved by enhancing the quality of its science work, increasing operational efficiency, building and maintaining strong partnerships, accelerating the use and impact of its research, and promoting greater cohesion, interdependence and alignment within the organization.

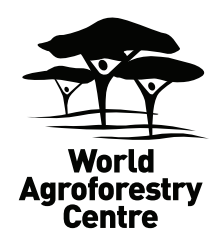

United Nations Avenue, Gigiri • PO Box 30677 • Nairobi, $00100 \cdot$ Kenya Telephone: +254207224000 or via USA +1 6508336645 Fax: +254207224001 or via USA +1 6508336646

Email: worldagroforestry@cgiar.org•www.worldagroforestry.org

East and Central Asia Regional Programme

\% Kunming Institute of Botany • 3/F North Research Building Heilongtan • 650201 Kunming • Yunnan Province • P.R. China Telephone: +86-871-6522-3014 • Fax: +86-871-6522-3377

Email: icraf-eca@cgiar.org•www.worldagroforestry.org/eca 